Modern Asian Studies 39, 4 (2005) pp. 929-980. (C) 2005 Cambridge University Press doi:10.1017/S0026749X05001861 Printed in the United Kingdom

\title{
Death and Celebration among Muslim Women: A Case Study from Pakistan ${ }^{1}$
}

AMINEH AHMED

University of Cambridge

'In my laughter there is grief; with sad eyes do I smile' (Pa khanda ke me jara da; pa khapa stargo khandegam) Ghani Khan.

'Not to Do Gham-Khadi is Shameful (Sharam); to Do it a Burden'

'Before there was little gham, now these ghamoona (pl.) have taken me off my rozgar' (employment) (Pookha ba kala kala gham wo was de ghamoona da rozgar a ooweesthama)

(From the popular contemporary Pukhto song 'Gham', sung by Rahim Shah).

\begin{abstract}
After September 112001 questions about the nature and society of Islam were asked all over the world. Unfortunately in the rush to provide answers inadequate and even distorted explanations were provided. Muslim groups like the Taliban in Afghanistan and Pakistan with their brutal ways came to symbolise Islam. The need to understand society through a diachronic and in-depth study was thus even more urgent. The following work is an attempt to explain how Muslims organise their lives through an examination of rituals conducted by women. This particularistic account has far-reaching ramifications for the study of Muslim society.

This article seeks to contribute to the general debate on Islamic societies. In particular it contributes to the ethnographic discussion on the Pukhtun. First, it seeks to establish the distinctive sociality of Pukhtun wealthy women or Bibiane in terms of their participation, within and beyond the household, in gham-khadi festivities, joining them with hundreds of individuals from different families and social backgrounds. Second, the article makes a case for documenting the lives of this grouping of elite South Asian women, contesting their conventional representation as idle by illustrating their commitment to various forms of work within familial and social contexts. Third, it describes the segregated zones of gham-khadi as a space of female agency. Reconstructing the terms of this agency
\end{abstract}

${ }^{1}$ This article is based on my Ph.D. thesis presented and approved at the University of Cambridge, Department of Social Anthropology (2004). The thesis is in the process of publication and acknowledgement is due to all the persons I mentioned therein.

0026-749X/05/\$7.50+\$0.10 
helps us to revise previous anthropological accounts of Pukhtun society, which project Pukhtunwali in predominantly masculine terms, while depicting ghamkhadi as an entirely feminine category. Bibiane's gham-khadi performances allow a reflection upon Pukhtunwali and wider Pukhtun society as currently undergoing transformation. Fourth, as a contribution to Frontier ethnography, the arguments in this article lay especial emphasis on gham-khadi as a transregional phenomenon, given the relocation of most Pukhtun families to the cosmopolitan capital Islamabad. Since gham-khadi is held at families' ancestral homes (kille-koroona), new variations and interpretations of conventional practices penetrate to the village context of Swat and Mardan. Ceremonies are especially subject to negotiation as relatively young convent-educated married Bibiane take issue with their 'customs' (rewaj) from a scriptural Islamic perspective. These contradictions are being increasingly articulated by the female graduates of an Islamabad-based reformist religious school, Al-Huda. Al-Huda, part of a broader regional and arguably national movement of purist Islamization, attempts to apply Quranic and hadith prophetic teaching to everyday life. This reform involves educated elite and middle-class women. These women actively impart Islamic ways of living to family members across metropolitan-rural boundaries. The school's lectures (dars, classes) provide a basis for questioning 'customary' or Pukhtun life-cycle practices, authorizing some Bibiane to amend visiting patterns in conformity to the Quran. The manipulation of life-cycle commemorations by elite and middle-class women as a vehicle of change, Islamization and a particular mode of modernity furthermore becomes significant in the light of recent socio-political Islamic movements in post-Taliban Frontier Province. More broadly, the article contributes to various sociological and anthropological topics, notably the nature and expression of elite cultures and issues of sociality, funerals and marriage, custom and religion, space and gender, morality and reason, and social role and personhood within the contexts of Middle-Eastern and South Asian Islam.

\section{Introduction}

This article explores the social lives of Pukhtun women or Bibiane (pl. of the Pukhto term 'Bibi': lady) from landed, well-off families in the regions of Swat and Mardan in northern Pakistan. ${ }^{2}$ Its

${ }^{2}$ The term 'Pukhtun' is widely used in three principal ways. First and more generally, all Pukhto-speaking people, the ethno-linguistic group predominantly living in Pakistan's North-West Frontier Province, are known as Pukhtun (or Pathan, Pashtun, or 'Afghan' [Hoti 1942]) by people living outside the Frontier areas. Pukhtuns are described as 'the largest tribal society in the world' (Spain 1995: 23), as 6o Pukhtun tribes comprise 6 million in Afghanistan and 10 million of Pakistan's total 2002 population of 147,663,429 (Khan, S. M. 1997; Shinwari 200o). Second, though the ability to speak the Pukhto language distinguishes the Pukhtun, speaking in itself is not sufficient; a Pukhtun must also 'do' Pukhto, i.e. seek to live up to a set of honour-based practices, also called Pukhtunwali (Barth 1981b: 105). Pukhtun identity is thus bestowed by adherence to notions of honour, especially in tribal areas 
ethnographic focus is on the enactment of specific life-cycle or ghamkhadi ceremonies (particularly funerals and weddings). The widely used Pukhto term gham-khadi both refers to specific segregated gatherings commemorating death, marriage, birth and other such events, and designates the emotions of sorrow ('gham') and joy ('khadi') which they elicit. Gham-khadi comprises a body of ideas and practices of life, in which happiness and sadness are understood as indissoluble, and are celebrated communally within networks of reciprocal social obligations. Preparation for and attendance at gham-khadi events is locally understood as 'women's work', a set of complex activities integral to Pukhtun identity or Pukhtunwali. ${ }^{3}$ Conventionally, writers on Muslim societies, particularly the Pukhtuns, have characterised Pukhtunwali as an 'ideal-type code' based on such principles as badal (revenge), melmastia (hospitality), nanawatee (refuge), tor (female honour), and tarboorwali (agnatic rivalry) (e.g. Ahmed, A. S. 1980; Barth 1986; Grima 1998; Lindholm 1982; Singer 1982); this article suggests that gham-khadi has come to assume a priority among Pukhtuns as a contemporary principle of Pukhtunwali. Many of the concepts characterising Pukhtunwali (such as forms of hospitality, revenge, agnatic rivalry) are acted out in funerary and wedding events (gham-khadi). I will argue that gham-khadi constitutes the 'work of life' (zeest-rozgar), through which Bibiane maintain the fabric of social life by sustaining inter- and intra-family relationships. ${ }^{4}$ Bibiane's sense of their gham-khadi obligations underpins their understanding of

where people are supposed to revert to 'ideal-type behaviour' (or Pukhtunwali) in order to be recognized as full members of society (Ahmed, A. S. 1980). Third, lineage and genealogy distinguish Pukhto-speakers from Pukhtuns, as landowning persons of the dominant Yusufzai tribe, descended from a common ancestor, and having a right to 'full citizenship' on the basis of previous conquest (Barth 1986: 3). In its $25^{8}$ interviews, at least, this work focuses on the Pukhto-speaking saintly and lordly landed families (particularly the Wali of Swat's, the Nawabs of Hoti, and Toru, and the Khanan of bar [upper] Swat).

${ }^{3}$ Pukhtunwali has been defined as the core of Pukhtun identity, and its social and cultural life (see Ahmed, A. S. 1980: 3, 89; Ahmed, Q. I. 1994; Banerjee 200o; Barth 1970: 119; 1986; 1995: 104; Grima 1998: xi; Khan, A. M. 1994; Khan, G. 1990; Khan, M. 200o; Lindholm, Charles 1982: 210 ; Mohmand 1966: 44; Singer 1982: $5^{1}$; Tahir 1980; Tair and Edwards 1982: 71 ).

${ }^{4}$ The western concept of the 'family' fits uneasily with indigenous models (see Altorki 1986: 13; Khan, S. A. 1996: 13; compare Le Wita 1994: 118; Shore 2002: 2), which involve extra-familial networks of alliance (Bourdieu 1991: 178). In the vernacular, the term 'family' is variably: a) the descendants of a single ancestor consisting of some twenty-five or more households but sharing one family name; b) a husband and wife unit; or c) a wife. 
personhood. The article identifies and explores a Pukhtun construction of work divergent from professionalism or physical labour measured and quantified by production output. What I seek to show is that the Pukhtun construction considers work as producing not things but social relations and transactions (Strathern 1990: 177).

This article is based on fieldwork carried out in three localities of northern Pakistan: Pakistan's capital city, Islamabad, and two villages (killee), Saidu in Swat and Hoti in Mardan, both in the North-West Frontier Province (NWFP). ${ }^{5}$ The districts of Swat and Mardan consist of several villages and may be characterised as segregated purdah contexts, in which patrilineal descent is common and marriage is typically both endogamous and virilocal. Swat is dominated by landowning Pukhtuns, referred to as Khanan; it was governed between 1926 and 1969 as an autonomous State under two Rulers, Badshah Sahib, and his heir, the Wali, who were descended from the famous shepherd Saint, the Akhund of Swat (1835-1877). The Akhund's male descendants are referred to as Badshahyan (as descendants of a ruler). Mardan is also dominated by landed lords or Nawabs, whose families, from the Patriarch Nawab Akbar Khan, were incorporated into British colonial rule as a landed elite. Women of both saintly and landed descent go by the honorific Bibiane. ${ }^{6}$

In both Swat and Mardan, the village (kille) is still, as Barth observed in the $195^{\mathrm{O}}$, 'the most important unit of territorial reference' for Pukhtuns (Barth 1986: 13). The Pukhto proverb: 'no matter how far you go, you'll eventually return to your village' (che ze ze no Abazai la ba raze) insists on an ideology of Pukhtun identity

${ }^{5}$ NWFP lies to the north west of Pakistan with its Western border or FATA, the Federally Administered Tribal Area, contiguous with Afghanistan along the Durand Line. The Frontier covers 41 ,ooo sq. miles. It is one of the four provinces of Pakistan and borders Afghanistan to the west and Punjab Province to the east; anthropologists have variously placed studies of the Pukhtuns under the two rubrics of Middle Eastern and South Asian Studies (Grima 1998: 2; Nelson 1974: 552). Donnan (1987: 21) attributes this definitional difficulty to the course of the Indus River across the southeastern Frontier as it marks off the sub-continent (see also Banerjee 2000: 21). Historically, the Yusufzai Pukhtuns conquered the Frontier in successive waves from 1500 to 1600 (AD). During British rule in India the Frontier served as a neutral zone, interposed between the two Imperial frontiers Russia and British India (Chakravarty 1976: 53; see also Richards 1990). The Frontier has retained its English colonial name despite many attempts to rename it Pukhtunistan (the land of the Pukhtuns) (Hanifi 1976: 442; Jansson 1988).

${ }^{6}$ My use of the plural 'Bibiane' refers to Pukhtun women from landowning families, not in terms of the Urdu usage, 'bibi/an', a gender-specific respect title for women of various social strata. 
being vested in its rural heartlands, as well as in Pukhtun villagers, who are said by many Khan and Bibiane to embody a purer form of Pukhto. While complex, village organization is shaped by the dominant role of landlords on whose hospitality, patronage and land ownership all other categories of villagers depend (Barth 1986: 3, 10). Khan status derives from tenants' allegiances and patrilineal land inheritances. Land is mainly agricultural in both the valley of Swat and plains of Mardan. Among the categories of villagers, farmers, tenants, agricultural labourers, shopkeepers, barbers, and dancers are all directly or indirectly dependent politically, economically and socially on landlords' families with whom they share reciprocal visiting relationships of gham-khadi. In addition to these, an entire category of male and female villagers belonging to these occupational groups as domestic helpers (wet-nurses, servants and maids) come to hold quasi-familial degrees of prominence and power in Bibiane's houses. Bibiane's performance of gham-khadi thus affects their relationships both with other families of equal status and a variety of socially subordinate villagers.

The importance of focusing on the funerals and weddings of Khanan and Bibiane as a social group is not that their embodiment of Pukhtunwali is taken to be more authentic than that of the gharib (poor), but that their practices have potential to disseminate more widely across village and metropolitan contexts. As many as two thousand people drawn from a broad social spectrum may attend big landlord families' funerals. As I have documented earlier, landlords' migration to the capital Islamabad is precipatating transformations in these Bibiane-villager bonds (Ahmed 2004). Transregional patterns of habitation mean that the observance of gham-khadi ceremonies in natal villages represents a vital ligature connecting often absent landlords to their traditional dependants and patrimony. Interactions between urban Bibiane and rural villagers demonstrate divergences in the understanding of convention, while the migration of Bibiane to a provincial region outside their own thus challenges some of the core features of Pukhtun 'identity'. This creates many painful paradoxes for Bibiane as wedding and funerary procedures are revised, and the acceptable forms of ethnic and cultural continuity called into question. $^{7}$

${ }^{7}$ On the topic of inherent paradoxes within forms of religion (Islam) and practice (Pukhto), see Ahmed, A. S. 1976; Tapper and Tapper 1986: 65; Titus 1998: 675 . 
Bibiane from Frontier families who have left the village context for the city, for at least some part of every year, form the ethnographic focus of this article. Married Bibiane in Swat and especially Mardan rarely leave the home for tasks not connected to gham-khadi (principally weddings and funerals, but also covering a range of other procedures of congratulation and condolence). These excursions, which take place as often as two or three times a day during the spring and autumn 'wedding season', and as infrequently as once a week in winter, tie them to a wide network of relations with hundreds of individuals from different families and social backgrounds.

According to an interpenetration of personal and social concepts of identity within Pukhtun conceptions of the family and kinship, Bibiane apprehend gham-khadi as both an enactment of social relations and a source of personal self-definition. A person's identity, as Daniel has argued, in a South Asian context, is not 'individual' but includes his or her spouse, offspring, kinsmen and so forth (1984: 103). ${ }^{8}$ Every adult of a given family-both men and women-occupies a unique position within a thick web of relationships in local, regional and national contexts. Kinship among Pukhtuns is typically conceptualized as dense and multi-filiated. Individuals conceive themselves as having relations not only to immediate kin (parents, children and siblings) but also to a range of distant relatives and affines, usually connected through the marriages of female relatives (who may be cousins several times removed). Bibiane's sense of social identity derives from a married person's participation in circles of gham-khadi formed primarily through kinship and marriage, but also through friendship, clientage and political faction. Likewise, families are conceptualized as large corporate structures, belonging to different households but sharing a common ancestor. Gham-khadi circle membership bestows on Khanan and Bibiane the obligation to attend fellow members' gham-khadi occasions, creating a complex pattern of overlapping bonds, loyalties, allegiances and debts between families (extended and nuclear). Each individual qua family member is bound to others by a pattern of reciprocal visiting.

At major gham-khadi, funerals and weddings, Bibiane engage in a number of practices of hosting (preparing the house, giving food) and

\footnotetext{
${ }^{8}$ In contrast, quoting Foucault, Rabinow writes: 'What is distinctive about Western culture is that we have given so much importance to the problem of the subject ['objectified by a process of division either within himself or from others'] in our social, political, economic, legal, philosophical, and scientific traditions.' (1986: 7).
} 
TABLE 1

Gham-Khadi

\begin{tabular}{lcccc}
\hline Pukhto: & gham & rogh-ranzoor & khadi & paidaish \\
Translation: & (sadness) & (well-ill) & (happiness) & (birth) \\
& $\downarrow$ & $\downarrow$ & $\downarrow$ & birth \\
Event: & death & illness/accident & wedding & $\downarrow$ \\
Performance: & laas-niwa & tapos (enquiry) & ombaraki(congratulations) ombaraki \\
& (condolence) & $\downarrow$ & $\downarrow$ & $\downarrow$ \\
& $\downarrow$ & $\downarrow$ & $\downarrow$ & $\downarrow$ \\
Offering: & money/food & money & money/(cloth) money(baby clothes) \\
Offerer: Wife or mother-in-law on daughter-in-laws' behalf (Iqbal 1997: 85$)^{9}$ \\
\hline
\end{tabular}

attending (gifting, offering congratulations or condolence), observing 'proper' or ritualized forms of procedure and decorum. Bibiane (and not their husbands) in these contexts characteristically offer money, food or gifts in accordance with family status and accounts (hisab-kitab) of earlier debts and donations:

These activities represent the most pronounced forms of a general social system of tlal-ratlal ('going-and-coming'), conceived of by Bibiane as an ongoing 'work of life'.

This account draws on local understandings of marriage and death that do not rehearse established anthropological distinctions between the two, since Pukhto idioms consider such distinctions foreign. Moreover, as annotated in Raverty's Pukhto dictionary, usages of 'gham' (sadness) and 'khadi' ('joy, happiness ... gaiety') (1982: 670) suppose essentially public or ceremonial contexts for emotions. A speaker may denote a defining condition (say, childlessness or widowhood) as their gham, as well as gesturing towards personal feelings. The spoken verb, 'khadi kawal', denotes the 'manifest[ation]' of 'gladness' specifically at weddings (wada), birth-visits (ombaraki), circumcisions (sunnat), naming and hair-shaving ceremonies (haqiqa), as well as less formal events such as returns from the haj pilgrimage, birthdays, election victories, professional promotions and housewarmings. Partly eliding the distinction between ceremonial and everyday visits, Bibiane specifically and Pukhtun people more generally place the term gham-khadi within the context of tlal-ratlal and a third expression,

9 Naveed-i-Rahat, in the context of Meharabad in Punjab (Pakistan) notes: 'Transfer of roles from senior to junior generation takes place in Meharabad not from mother to daughter but from mother-in-law to daughter-in-law.' (1990: $5^{8}$ ). Further, Mernissi notes: 'The mother-in-law's role as imitator of savoir-vivre is as important as her role as instructress in matters of birth, sickness, and death.' (1985: $126)$. 
zeest-rozgar (literally the 'work of life'), thus confounding any anthropological attempt to establish a separate ontology of gham-khadi ceremonies (compare Humphrey and Laidlaw 1994). Pukhtuns use variants of the word 'rozgar' in contexts other than gham-khadi, referring to professional work ('kaar-rozgar') as 'employment', which is distinguished from less specified purposive activity, 'kaar' ('kor-kaar', housework). The word tends to relate more to people's roles or identities than to the effort invested in contingent tasks. The two available English-Pukhto dictionaries amplify these verbal transfers in defining zeest as 'life, existence, employment' (Bellew n.d.: 88; Raverty 1982: 537), and rozgar as 'employment', 'service, earning', and also 'time' (Bellew n.d.: 82; Raverty 1982: $5^{16}$ ). Bibiane's own discourse suggests that visiting, gifting and attending ceremonial events are all parts of a conceptually single, though highly complex, process of 'making kinship' (Carsten 1997) and building social relationsa process, moreover, experienced as a form of work.

Such a concept of 'work'-first, a practice of social relations not completely identified with any one task; and second, an array of conceptual (not only physical) activities-necessarily complicates and enriches debates within anthropology and sociology as to the definition of this term. ${ }^{10}$ In the 1970 -80s, a number of women anthropologists took issue with the broadly Western conceptualisation of work as a salaried, professional task taking place in a public sphere, adducing the domestic context of socially meaningful labour (Mackintosh 1979: 175; Povinelli 1993; and Strathern 1984: 13, 18). Others criticized the then-dominant model of work as 'patriarchal' (Grint 1991: 33, 40; Kondos 1989: 29; Lewenhak 1980, 1992: 1, 16; Morris 1990: 3-5; Novarra 1980: 35; and Wallace 1987: 1). This account builds on this work by presenting an ethnically specific concept of Bibiane's 'work' as they enact 'proper' ceremonial observances. Attendance and participation count as Bibiane's work under a number of headings: first, these actions entail conformity to or negotiation with conventional practices; second, they are physically and mentally arduous (a matter of strategy); third, the participating women

${ }^{10}$ Western female anthropologists have been at pains to problematise assumptions about work, e.g. Andersen, M. L. 2000: 144; Franks 1999: 4; Gray and Mearns 1989: 29; Hochschild 1997; Humphrey 1992: 179; Kelly 1986; Mackintosh 1979: 175, 179-190; Novarra 1980: 22-25; Oppong 1994: 1-1 3; Pahl 1989; Reagan and Blaxall 1976: 1-5; Singh 1992: 3; and Wallman 1979: 12-13. On other activity in the hidden economy as 'work' (Daniels 1988), such as voluntary work, see Jahoda 1982: 8-9 and on charitable work, see Reynell 1985: 232-233. 
collectively perform a 'work' as a means of Pukhtun self-representation ('Pukhtunwali'); and last, they are understood by Bibiane as an ongoing social effort, characteristic of living itself. The analytical concept of 'work' I deploy identifies the term with the small- and largescale, highly organised, transactional activities that make up social relationships. Bibiane's entry into a gham-khadi circle, on marriage, commits them to a category of social relationship with other families in which gham-khadi obligations subsume all other ties, as gham-khadi and tlal-ratlal participants understand themselves to be performing an identity-making practice of 'Pukhto'.

This account aims to build upon a rich body of anthropological literature about NWFP Pukhtuns, from a female and 'social', rather than political context, for its representation of the actions of individual Bibiane in gham-khadi. ${ }^{11}$ Most anthropological enquiries in the NWFP discuss 'tribal' village contexts (Donnan and Werbner 1991: 3). ${ }^{12}$ Barth's account of political leadership among Swat Pukhtun Khans ('chiefs' or landowners) of the Yusufzai tribe $(1986)^{13}$ showed that although Pukhtun society, in theory, is egalitarian, in reality, it is structured by caste-like divisions. The 'Pukhtun' (conventionally landowning and widely referred to as Khan) forms the apex of such structures, along with certain religious groups (for example the Wali's Family). Barth argued that Khans derive authority from the ownership of land, provision of hospitality, and reputation for honour. In Swat,

${ }^{11}$ Ahmed, A. S. 1975, 1976, 1980, 1984, 1988; Asad 1972; Banerjee 20oo; Barth 1958, 1959/1986, 1960, 1961, 1970; 1981a, 1981b, 1995; Caroe 1992 (1958); Dupree 1978, 1984; Edwards 1996, 1998; Grima 1998; Lindholm 1981, 1982, 1988, 1995, 1996; Safdar 1997; Singer 1982; Shah, S. I. 1993; Shah, S. W. A. 1999; Spain 1962, 1963, 1995. On Afghan Pashtuns, see Lamb forthcoming; Tapper and Tapper 1986; Tapper, N. 1981, 1991; Tapper, R. 1984. Historical and colonial accounts include Bellew n.d., 1986, 1994; Beveridge 198; Elphinstone 1815 ; Goodwin 1969; Howell 1979; King 1984; Kipling 1987; Merk 1984; Raverty 1982; Thackston 1999.

${ }^{12}$ A Pukhtun 'tribe', in this context, means the group of people who claim descent from a common ancestor, Qais bin Rashid in the $7^{\text {th }}$ century, who had three sons: Sarband, Bittan and Gorgosht, from whom all Pukhtun tribes trace their descent. All Pukhtun tribes also share a common 'culture' called Pukhtunwali; speaking a common language, Pukhto; and usually occupying a specific geographical area, such as the North-West Frontier Province in Pakistan. For a definition of 'tribe' in the Middle Eastern context, see Khoury and Kostiner 1990: 4.

${ }^{13}$ Amongst the Pukhtun tribes the Yusufzai Pukhtuns who make 'the class of khansand Pukhtuns' (Lindholm, Charles 1996: 78) aspire to 'positions of leadership' (Lindholm, Charles 1982: 213). They are one of the most powerful tribes in the Pukhtun hierarchy. Both Mardan and Swat regions are dominated by the Yusufzai Pukhtuns (see Ahmed, A. S. 1976: 7, 1977a: 14; Barth 1986: 7-1 1, 25-28; Bellew 1994; Caroe 1992: 12-13; Wadud 1962: xxiv). 
Khans, in the capacity of autonomous agents, build support and status by receiving visitors in their men's guesthouse (hujra). In a series of 'games', both the landed (mōr sarī: satisfied men) and their adherents (wúge sarī: hungry men) are granted an individualistic agency in exploiting their respective resources (land or support and labour). Barth argued that in a series of temporary choices, relationships are dyadic, contractual and voluntary (ibid.: 3). In contrast, I argue below that although Bibiane are able to exploit relationships within society to further their individual choices through gham-khadi, such relationships are, however, characterised by a complex sense of duty and obligation.

Although Barth's focus on singular actors, agency, and negotiation marked a new phase in anthropology (from that of Evans-Pritchard's and Radcliffe-Brown's models of social structure), and was the first substantial ethnography on 'elite' Pukhtuns, his theoretical presuppositions were challenged variously by Marxist, indigenous, and feminist scholars. Asad (1972) argued that Barth obscured Khanans' exercise of systematic domination through their control of scarcity. Second, Ahmed questioned Barth's western presumption of individual interests, which downplay the emergence of the selfabnegating Ruler (Badshah) or Wali and his Sufi ascetic ancestry in Swat (Ahmed, A. S. 1976; compare Comaroff and Comaroff 1992: 10, 16; Dupree 1977: 514). Third, feminists have also proposed a revision to Barth's 'political' conceptualisation of power, presenting power less as a quality vested in certain institutional offices or factional leaderships (like the Khans'), and more in terms of a 'particular kind of social relation' (Nelson 1974: 553). ${ }^{14}$ In these terms, Bibiane's activities of 'brokering' 'information', 'control' and 'influence' through the 'negotiated order' of gham-khadi (Nelson's terms in her germinal 1974 article on women in the Middle East) achieve new theoretical visibility (compare Roded 1999).

This account of Bibiane's gham-khadi as an important form of Pukhtun social activity explores new dimensions and perspectives only partially investigated by both Muslim and non-Muslim scholars. ${ }^{15}$

\footnotetext{
${ }^{14}$ My interest in women does not necessarily entail feminism as a theoretical stance (Strathern 1990: $3^{6}$ ).

${ }^{15}$ More widely, however, forms of South Asian and Middle-Eastern women's visiting and feasting have been extensively documented (see Das 1986; Khedairi 2003; Sharma 1980: 234; Tapper, N. 1991, all are gender-specific female activities around life-cycle events in India, Iraq, and in Afghanistan. For Bedouin and Turkish Muslim women's practices of bonding through visiting and exchange, see Abu-Lughod 1986; Aswad 1978; and Delaney 1991: 14 [contrast, also, Sexton 1984; and Strathern 1990]. See Gilsenan (1990) on Arab women's visiting). Striking parallels are Shaw's
} 
In the context of Frontier ethnography, Barth viewed gham-khadi ceremonies as an adjunct to Khan factionalism, understanding the strengthening of affinal ties at weddings and funerals as essentially political acts (Barth 1986: 40, 41; compare Ahmed, A. S. 1980: 177). Charles Lindholm gives greater weight to female agency in describing the activities of 'Khan women' in organizing gatherings (1982: 134) in the village. Lindholm describes women's position in terms of 'the centrality of the womb in a system that denies the existence of women as independent entities' (ibid: 159; see also 1996). Thus, the organization of Pukhtun society 'on the basis of kinship' subordinates women to an essentially transitive role in the transfer of lineages and consolidation of patrimonies (Lindholm 1996: 74). Grima's ethnography of the lives of Pukhtun women offers a more substantial account of gham as an emotion centrally 'performed' in women's self-conceptualisation and narration. However, in focusing on 'poor families' (1998: 28), Grima overlooks the Bibiane; and attributes far more emphasis to gham, rather than noting its complementarity with khadi.

My account describes Bibiane's gham-khadi as segregated but not apolitical. ${ }^{16}$ In suggesting places to look for Middle Eastern female agency, Tapper argues that any society prohibiting women's access to a professional sphere tends to develop alternative, quasi-autonomous female networks of circulation. Gossip and gifts between women demarcate a 'sub-society' serving as a 'psychological outlet... in a situation of male domination' (Tapper 1978: 395), as women exercise both tacit and overt forms of jurisdiction over the domestic environment. Yet, in the Frontier, female visiting reflects and underpins Khanan and Badshahyan's explicitly political positionbuilding. In a country in which its elite maintain dominance by controlling appointment to influential political positions (Khan, A. 2003: 31-32), ${ }^{17}$ Bibiane's canvassing on behalf of male familymember MNAs and MPAs (Members of National and Provincial

account (1997) of the Punjabi reciprocity 'lena-dena (gift-giving)' which corresponds to the Pukhtun warkra-rakra [give-take] gift giving; and Nancy Tapper's kheyr-u-sharr (good-and-evil) among the Shahsevan Iranians (1978) is comparable to the Pukhto kha-bade (good-bad).

16 'Females ... play a full part in the political and economic life of the Pukhtuns $\ldots$ an aspect of society ... overlooked for lack of data and therefore ... unanalysed' (Ahmed, A. S. 1980: 15).

${ }^{17}$ On the continuing hold of elite tribal families in Pakistan's national politics, see Khan, A. 2003; Weiss 1991: 2. In 1999, 126 of the 207 National Assembly seats were 
Assemblies) at Bibiane's ceremonies, brings them into contact with circles of a wide range of people (rich [maldar] and poor [gharib], from various familial, ethnic and multicultural backgrounds). ${ }^{18}$ Bibiane command a significant degree of respect on the basis of family history but at the same time they must also put much time and effort into the work of reputation-building in the household, village and gham-khadi network analogously with their husbands' 'political' efforts.

Recognizing that Pukhtun Bibiane practices overlap with a political arena necessitates the reformulation of an idea of the public sphere from the 'inside-out' (Gray and Mearns 1989). Female anthropologists have challenged the equation of a governmentally administered work-space in the 'public' realm, with the home being considered a lesser, 'private' domain. The division deprived domestic women and children of status, self-determination, and even complete personhood (see Colen and Sanjek 1990: 4; Strathern 1984: 31 ; 1990: 133; also Waterson 1990: 169). ${ }^{19}$ Both Western and non-Western anthropologists working in South Asian, and particularly Muslim contexts, have tended to apply this framework to indigenous contexts (see Deutsch 1998; Kondos 1989: 165 and 176; Papanek 1982: 28; Sharma 1980: 214 and 226; Weiss 1998: 125), despite the lack of Islamic categories that correspond to Western notions of 'privacy' (Cook 2000: 80). ${ }^{20}$

The theoretical premise of the 'inside-out' approach allows social relationships to be delineated from the perspective of women observing purdah. In the context of her work in Papua New Guinea, Strathern (1984) calls for the 'dislodg[ing]' of one's thought from a

held by members of the Frontier Khans, the Sindhi waderas, Punjabi zamindars, and Baluchi sardars.

${ }^{18}$ Donnan and Werbner (1991) also note a large number of Pakistani migrants live in Euro-American and Middle Eastern cities; see Raj 1997; compare Shaw 1997, 2000, 2001; and Werbner 1992.

${ }^{19}$ On the Greek origins of the western concept of 'work', see Grint 1991: 15 . On work outside the house as a salaried male occupation differentiated from women's domestic tasks, see Weber 1968: 21-22; Hoch-Smith and Spring (eds.) 1978.

${ }^{20}$ In a South Arabian context, Gilsenan dichotomises gendered space (1990: $17-$ 173), as does Barth (1983: 74). Price furthermore alleges the tendentiousness of many academic appropriations of local (Indian) formulations of the 'public' (2000: 28). Compare Reiter 1975. On a critique of the 'private-public' dichotomy, see Abu-Lughod 1986b; Habermas 2002. Henrietta Moore suggests 'even where such a distinction exists we must not assume that the Western terms ... are adequate or reasonable translations of the categories other cultures perceive' (1997: 20). Within the context of Pakistan's Yasin Valley, York argues that the private and public domains are flexible and tend to overlap (1997: 209, 216 ). 
binary Western matrix of 'work [inside and] outside the house' if the full complexity of affiliation between kin, affines and dependants is to be captured. This is a perspective that I seek to apply to the Pukhtun house as a place where both male and female (segregated) work, especially the work of gham-khadi, assumes a public aspect. At weddings and funerals the familial house is thrown open to all, with men visiting the hujra (men's guesthouse) and women the kor (house). Rather than dealing with these spaces according to any implicit hierarchy of importance (Grima 1998: 71, 118; Tiffany 1984: 6), I refer here to the bazaar and other external spaces as 'the non-segregated public' and the house during gham-khadi as the 'segregated public'. ${ }^{21}$

\section{The Paradoxes of Gham-Khadi}

This section examines the problematic and stressful aspect of ghamkhadi as experienced by Bibiane in their reflection upon diverse areas of their lives. The performance of gham-khadi prompts women to think about its relation to Pukhtun categories of religion and 'custom', right and wrong, the individual and the collective, and the obligatory and the voluntary. Unlike other customs less identified with a philosophy of life or with particular celebrations, gham-khadi falls neither on one side of these dichotomies nor the other, but rather cuts across them in such a way as to arouse painful dilemmas for Bibiane. My analyses here begin to expose how gham-khadi is problematic for Bibiane in bringing to the surface deep-lying social contradictions, which demand some practical resolution, given the priority granted to gham-khadi (or zeestrozgar) over forms of professional employment (kaar-rozgar), childcare and housework (kor-kaar).

The term gham-khadi, as used by Bibiane, refers not merely to wedding and funeral ceremonies and procedures, but to a sense

\footnotetext{
21 'We call events and occasions 'public' when they are open to all, in contrast to closed or exclusive affairs' (Habermas 2002: 1), as gham-khadi is understood to be. In the 'all-women context' of gham-khadi, Grima observes: 'every social interaction is public to a degree. There is not so much an opposition between public and private as ... a continuum stretching from 'less public' to 'more public'. The interaction between women, even if it takes place inside the house, has a very public aspect to it.' (1998: 71, 118). See also Ahmed, A. S. 1980: 243; Barth 1981b: 28, 1986: 31 . In a Middle-Eastern context compare Abu-Lughod 1998b: 26o; Altorki 1986; Altorki and El-Solh 1999: 44; Aswad 1978; and Tapper and Tapper who refer to the 'public context of hospitality, especially in life-cycle feasts.' (1986: 74).
} 
of social obligation underlying the performances. Gham-khadi as a principle of Pukhtun life and thought may be characterized not only in terms of the organizing schemes above, but also as a negotiation between the poles of each; it is not simply the implementation of any single principle. The questions I now ask are: should gham-khadi be collectively understood as having prior terms of enactment, or as subject to individual manipulation and strategy? Is gham-khadi for Bibiane governed by patterns of reciprocity that exclude personal choice, or does it represent a kind of morality, accessible to the subjective judgments of groups and individuals? If gham-khadi is an ingrained feature of Pukhto, then is it in conformity with present-day understandings of Islam? Can the obligation to perform gham-khadi be made congruent with the Western idea of a professional career for women outside the home? This article draws on my observations and discussions with Bibiane, representing gham-khadi as the place where a number of normative and definitional concepts of gender, personhood, propriety and tradition are knotted-and are beginning to unravel.

Bibiane see the activities associated with gham-khadi-preparation, travel, financial and household management-and the consolidation of kin relationships through acts of attention and politeness as a form of 'work'. However, the injunctive force of work does not make gham-khadi an unproblematic performance of (a number of) narrowly-defined acts. Bibiane describe their 'layered' lives in terms of ambiguities and contradictions-between city and village, home and school, hujra and kor. The fundamental paradox of gham-khadi (sadnesshappiness) as a verbal formulation is yet more intractable in practice, in the sense that a funeral may take place in one village the day after a wedding in another. Bibiane also experience the paradox enshrined in the phrase in a series of daily quandaries as gham-khadi obligations may clash with other projects they wish to pursue, such as education, full-time employment and childcare.

Different gham-khadi occasions are categorised in a hierarchy of importance with attendance at gham (the paramount emotional, thoughtful and bodily experience) taking priority over khadi. The scale descends through illness (najorthia), birth (paidaish) and relatively minor tapos (enquiries) on moving, afsos (condolence) following an election defeat, or felicitations (ombaraki) to winners. Thus, were a death and a wedding in two separate families to fall at the same time, an individual expected to attend both should go to the funeral (gham) (see Lindholm, Charles 1982: 156). References to gham-khadi are pervasive in people's accounts of their social experience. Bibiane 
and Khanan feel an overwhelming sense of responsibility in complying with expectations concerning their attendance, gifting, deportment and dress; this generates an agitated moral discourse of judgment and self-scrutiny. As husbands depend on wives to undertake gham-khadi on behalf of their households, the practices represent an instance of female power within a supposedly 'patriarchal' framework (Papanek 1982: 37; Shaw 1997: 149). Meanwhile, the specificity of gham-khadi as a distinct set of conventions between religion and Pukhto, moral choice and compulsion, grants it a language of its own.

\section{Collective and Individual in Gham-Khadi}

Gham-khadi in Pukhtun experience comprises a constant feature of life as lived and understood, yet is complex, contradictory and subject to transformation (Comaroff and Comaroff 1992: 38). One of the dimensions in which Bibiane see gham-khadi changing is in the different types of responsibilities required of individual subjects over the course of their lives. Another dimension concerns the alwaysmutable question of social status (of both individuals and families) as negotiated through gham-khadi observances. Much of the complexity of gham-khadi inheres in its bridging of two levels: that of collective performance, and of individual responsibility.

At one level, collective co-operation, through attendance, gifting, and consumption of the feast-meal, is deemed essential to the correct performance of gham-khadi. The success of an event and the prestige of a particular family are judged by the number of people (khalak) attending their wedding or funeral (see Ahmed, A. S. 1980: 243, 288; Barth 1986: 32). A large attendance maintains honour, while scant attendance may lead to the ostracism of "the person whose gham/khadi it is. It is as if she is not "recognised": she is "no-one" in society.' Sumaira, in her late thirties, originally from Swat, married to her matrilateral parallel cousin from Mardan and now living in Islamabad, explained the significance of gham-khadi to me in English:

Gham-khadi has this importance, from roz-e-awal (Persian: from the beginning) both for men and for women, like when people get together collectively for prayers in a mosque. Why? The importance of this is that people come together collectively and understand and share each other's dokh dard (Urdu: sorrow and pain). It's a community feeling. Tomorrow, God forbid, if it is your sorrow or illness the same people will ask and come to you when you need them. 
In gham-khadi, the collectivity of kin and affines assembles from the same and other villages, cities and even foreign countries to gather at the site of origin. The gham-khadi event in this manner places emphasis on Pukhtunwali both in regulating social relations and on an individual level, is an important constituent in the self-understanding of urban or emigrant Pukhtuns. In the case of one wedding, a Bibi who lived in the U.S.A. with her Pukhtun husband praised ghamkhadi for joining dispersed relatives. With increased global transport and communication, gham-khadi becomes crucial in the affirmation of people's Pukhtun identity. Close relatives living abroad are expected to return for the ceremony (compare Shaw 2000; Werbner 1986); and more distant relatives phone. The work in gham-khadi makes itself felt in the literal and physical cost of travel and attendance.

Against an emphasis on collectivity (and cases where parents may act for married children, or wives for husbands), every adult individual is ultimately responsible for performing reciprocal cycles of 'going and coming' with his/her wider social network. Participation is said to engage different dimensions of personhood-the body (jismi zor: physical effort), mind (dimagh: intellect), and emotions (zre, heart). Bibiane are expected in a generalised moral register to keep up relationships with kin and affines (through visiting, solicitude, ghamkhadi attendance), and also to carry off social performances in the ceremonial context (presenting oneself to the senior women of the afflicted or celebrating household, addressing people correctly by seniority and family closeness, gifting correctly and in accordance with an accepted procedure). Despite the usual practice of husband and wife attending gham-khadi together, in segregated spaces, individual women are understood as agents exercising control over these forms of behaviour. Actions in such a context inform a public view of one's female morality, in which 'psychological' and 'social' components are indissoluble. A common proverb is repeated among Bibiane, 'khpal ezat pa khpal laske de' (one's own ezat [honour] is in one's own hands; compare Altorki 1986: 135; Lindholm, Charles 1995: 64). If distinct styles of behaviour are expected of Bibiane in gham-khadi contexts, then it is also understood that women may fall short of them. Thus two orders of moral thinking interlock in the context of gham-khadi: first, women's adept or inept performance of repeatable procedures; and second, individuals' knowing deviation from them (for example, through notably ostentatious or self-effacing styles of self-presentation).

The actual deployment of tactics in socializing and presenting one's gift as a household-head in ceremonies is far more subtle than 
schematic moral ideas of good/bad and conformity/deviance would suggest. Each woman (responsible for more than herself) in the act of giving money on behalf of her own family (and husband) will take great care to register her action both with the recipient and the attending assembly of women. She will announce her contribution, writing 'from Mr. and Mrs. Khan', for example, on the envelope. Bibiane are concerned to make an impression through the way in which they arrive and present their offerings, taking care to acknowledge the senior women of the household. Persons seek to maintain a respectable public face, even, in some cases, at the cost of excluding or asserting precedence over others. These manoeuvrings of position and status within extended families, with competing sisters-in-law, other affines, and step-relations (co-wives and their children), make ghamkhadi the site of peculiar conflicts. ${ }^{22}$ These forms of female rivalry are often treated light-heartedly, with an undertone of deeper feeling. An approaching sister-in-law may be derided sotto voce as a 'balla' (monster) or 'badda' (bad), before being greeted cordially. Thus, under the cooperative and collective sense of gham-khadi often lies another level of relationships fraught with competition, tension and even enmity.

Tension coexists with forms of tutelage into Pukhto procedures, as affinal relations (mothers-in-law and sisters-in-law) teach brides how to perform correct gham-khadi in the context of their own extended families. Scholarly accounts from the wider Muslim world, specifically South Asia, recurrently note the role extended families play in shaping individual behaviour. In her account of joint family households in rural Rajasthan, Kolenda notes that early marriage necessitates 'the joint family function[ing] as [the] protector and guide of young couples' (1989: 103); for newly married Bibiane, this protection extends to their training as workers in gham-khadi. Nazia (aged 45 at the time of this conversation) recalled:

I was only fifteen when I got married. But my yor (husband's eldest brother's wife) taught me everything, like dressing up and how to meet people in gham-khadi. She has trained me the way you train your own daughter.

The mutual obligations of gham-khadi define for Bibiane the particular social and familial networks in which they will engage during the course of their lives. Older informants told me that every family has their specific riwajoona (ways/customs) of gham-khadi (i.e. who with

${ }^{22}$ On competitive rivalry and 'upping the ante' among Pukhtuns, see also Grima 1998: 75; and Lindholm, Charles 1982: 74, 191. 
and how they do gham-khadi), both in terms of whom they favour with attendance and their procedures of visiting, gifting and recognising reciprocity. Arrangements between families vary according to the

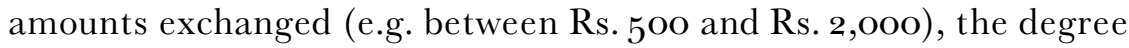
of non-kin attendance for political families and expectations of exact financial reciprocity for poorer scions. Beginning the performance of gham-khadi can be a daunting and bewildering experience for young women, who are treated as full independent moral agents for the first time. A non-Pukhtun wife of a Pukhtun Khan, Aliya, captured (in English) the difficulty of establishing new affinal relationships:

If you do not attend gham-khadi they say: 'she doesn't want to be part of the family'. It's very clannish. It took me a long time to understand that all these women are all cousins; and cousins of their husbands. If I don't go they say she is an 'outsider', and I am pushed out more. So I work hard to meet these people.

In-marriage, as proved time and again in family gham-khadi gatherings, is proposed as making of kinship in two ways: not only does the non-consanguineous bride affiliate herself with the relatives of her husband, but also works at building relationships with a network of household spouses who are also cousins, overcoming a further kin boundary. When such a woman integrates herself successfully, her choices in terms of small acts of compliance with group norms will have bound her to the collectivity of her affines.

\section{Reciprocity and Morality}

In committing herself morally to a gham-khadi relationship, a Bibi reciprocates another's attention firstly with respect to time and presence, and secondly with respect to money. The quality of visiting is evaluated by the amount of money given, immediacy of attendance, and time stayed (from morning to evening for three days for a wedding, or forty days for a funeral). All these represent criteria for how 'well' a bond has been discharged. The identity of gham-khadi as a form of reciprocal tlal-ratlal in theory guarantees a return on visits paid. Financially, this reciprocity takes the normative form of receivers giving back more than they were offered. One Bibi observed: 'You come to my house [for ombaraki] and give me a gift [customarily money]; in return I must go to your house for the same duration of time and pay back the equivalent or more, but never knowingly less 
[although in practice some people give according to their means].' Attendance at others' festivities is more important than money itself, and determines whether a relationship is sustained or ruptured. The gift of one's presence at ceremonies is normally, however, accompanied by a financial subvention, and vice versa; both together signify the continuance of family bonds (Abu-Lughod 1986: 69). To borrow Mauss's terms (1990), gham-khadi gifts do not exist as isolated and unsignifed objects, but rather carry a symbolic part of the donor: in a display of hospitality, women offer their guests their unconditional attention, time and presence. The gift of money also represents and embodies the donor and receiver's social relationship. ${ }^{23}$

Procedures for the presentation and reception of gifts of money are calibrated to the family relationships of both donor and recipient and, more markedly, the recipient and the 'subject' of the gathering (the dead person, the new-born baby, the bride's mother or female guardian). Bibiane may accept money from gham-khadi guests in different capacities: as brides, mothers of new-born babies, wives of ill husbands, or widows. At weddings, a bride's mother, who stands at the entrance of the wedding reception, will be greeted by each arriving guest, then handed an envelope containing money (this may vary from Rs. 200 to Rs. 2000). This money is meant for the bride, and her mother hands over all the envelopes to her daughter after the ceremony. The mother may at this point write down the names and amounts of money given by each guest, often assessing her relationship with each woman according to the amount of money given. This list will be an important reference for the bride in her future reciprocations as, until individual sums of money are repaid, the receiver is in a state of debt.

Expectations of reciprocity in gham-khadi practically affect Pukhtuns in their day-to-day existence. Among the gharibanan (poor), many maintain a public image by large sums for gifting and hosting ghamkhadi events. ${ }^{24}$ Maids may depend on their Bibiane as patrons from

${ }^{23}$ On unreciprocated or free gifts in 'Jain society', see Laidlaw 2000, who theorises that 'The self-negating free gift is [. . .] present, even if only for a moment, in the transactions which make up systems of reciprocal gift exchange.' (ibid: 628).

${ }^{24}$ One gharib woman told me: 'Here (in Mardan) there is a wedding of a widow's son the jore (suits), clothes, the rice, everything-are qarz (loaned). I told the woman: "what is the sense in taking so many loans?" The mother of the groom replied: "people will laugh at me if I don't have these things to show at my son's wedding"'. The speaker herself did not 'give a single meal' at the marriage of any of her four sons due to her unwillingness to take out a qarza (loan). 
whom to borrow large sums of loans (during my fieldwork I knew three maids who borrowed more than Rs. 10 ,000 (£105) in one transaction from Bibiane for their families' gham-khadi). If someone is na-chara (very poor), they procure loans (qarz) from village shopkeepers, wealthier relatives, and neighbours. Many of these loans lead to life-long debt. ${ }^{25}$ Financial gifts pass not merely between members of different households, but also, in a generally more symmetrical arrangement, between affines. The morning after her wedding, a bride also receives money from the closest of her husband's relatives: her married sistersin-law (both her husband's sisters and his brother's wives) and motherin-law, who typically determine amounts beforehand, so that all sisters-in-law give equally. The inscribed envelope is then presented to the bride with large sums of ombaraki money. In Mardan at the time of my fieldwork, close relatives such as first cousins or sistersin-law gave Rs. 10,000 to brides; in Swat some Bibiane even reported

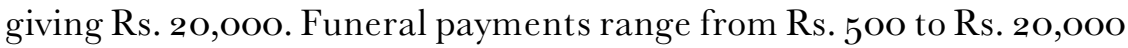
for a very close relative. Births 'cost' from Rs. 200 to Rs. 2000, and illness upwards of Rs. 5oo. Distant relatives are not required to underwrite funeral expenses, though a wealthy elder who did so would be thanked after the gift had been politely refused in sath. The differences between funeral and wedding gifting point to the greater closeness of relatives in sharing grief; khadi are happier occasions, in which all may participate. Very tentatively, though, the movement among elite Pukhtuns from closely reciprocated patrilateral cousin marriages to exogamy suggests that khadi contributions keep alive a family's possibility of later marrying into the circle (benefitting from the 'good' of a bride or giving a bride).

Without ceasing to be obligatory, Bibiane's responsibilities in ghamkhadi are graded according to their household seniority. ${ }^{26}$ One of my older informants, Bibiji (aged 6o), stated: 'Masharan [elders] give more in weddings and births of people not so close (distant relatives) about Rs. $5^{\text {Oo }}\left(£_{5}\right)$ to Rs. 1000 (£10) while kasharan [younger women] give less about Rs. 300 (£马).' According to my observations and the statements of younger Bibiane, however, this was rarely the case.

25 ' $[\mathrm{H}]$ ospitality and the large-scale entertainment required at gham-khadi events were the greatest burdens on the family economy, leading to the heaviest debts' (Grima 1998: 43).

26 'Social status, [is] measured through conspicuous consumption and as part of Pukhto tradition, is maintained by senior lineages although their incomes may be considerably lower than junior or non-Pukhtun groups.' (Ahmed, A. S. 1980: 287; see also 288). 
TABle 2

Money given by Bibi for gham-khadi during a Four-month Period (March-June, 20oI)

Deaths

Cash

1) Brother's wife (wrandar)

2) Older sister (khor)

3) Sister's husband (ookhe)

Food Offerings

4)Husband's brother's

son - (lewarzay)

Weddings

Relatives (khpalwán)

$$
\begin{aligned}
& =\text { Rs. } 5^{\mathrm{OOO}} \\
& =\text { Rs. } 5^{\mathrm{OOO}} \\
& =\text { Rs. } 1000
\end{aligned}
$$

(five darai of) Rice, sarwe (1 cow) and sanda

$(1$ buffalo $)=$ Rs. 10,900

Usually varies from Rs. 500-10,000, but due to the many deaths of close relatives there were no weddings in the Bibi's family during this year. Amount given $=$ None

Non-relatives (pradee).

= Rs. 1000 (varies from Rs. 100-Rs. 2000)

Births

Amount given for

$=$ Rs. 2000

two ombaraki

Total

$=$ Rs. 24,900

Bibiane in their twenties and thirties reported giving between Rs. $5^{\text {OO }}$ $\left(£_{5}\right)$ to Rs. 20,000 (£210) for weddings, and Rs. 5 oo to Rs. 2000 (£2 1) for births. The younger women considered the amounts suggested by Bibiji as far too little and 'embarrassing'; many women remarked that the larger sums they gave symbolized the value which they placed upon their relationship with recipients. Larger sums may also reflect younger Bibiane's anxiety to grow roots in their marital families. A young 25 year-old Bibi told me that she wanted to give Rs. 2000 for the birth money of a very close friend, who was also her affine, but just before visiting their house, her mother-in-law interceded, causing her to reduce the amount to Rs. $5^{\text {OO }}\left(£_{5}\right)$ in proportion to the elder woman's gift of Rs. 1000 ( $\left.£_{10}\right)$. The amount of money younger women give in gham-khadi clearly exceeds the amounts given by masharan (elders), suggesting younger Bibiane's gifts express degrees of voluntarity.

Table 2 above is an estimate of a mashara (elder) Bibi's spending on gham-khadi within a period of four months.

The above total amounts to a large sum of expenditure by local standards. ${ }^{27}$ Another Bibi estimated spending approximately one lakh

${ }^{27}$ In comparison a wealthy Khan's annual income may range from 10 to 12 lakh rupees $\left(£_{10}\right.$,OoO $-£_{12,000)}$ and a maid's pay may average from Rs. 2400 (£25) to Rs. 20,000 (£210) a year. 
rupees a year on gham-khadi: 'I give Rs. 20-30,ooo for relatives' death'. South Asian scholars confirm the major economic impact of funerals and weddings on Pukhtun families, not merely among Khanan but across social classes (Ahmed, A. S. 1980: 285-288; Barth 1986: 32; and Grima 1998: 43; compare Metcalf, P. 1982; 21 ).

Maids and daigane participate in the reciprocal gift economy of ghamkhadi in a number of ways. Though maids and daigane may accompany their Bibiane on all their gham-khadi, they do not normally give money to Bibiane (wet-nurses may give, however; in one case I observed a dai give Rs. 100 as a birth ombaraki to a particular Bibi). Among villagers the expectation of gifting is not waived, even for poor married maids who give the same amount as other villagers: between Rs. 100 to Rs. 200 for a close relative's death, and either Rs. 3o, Rs. $5^{\mathrm{O} \text {, or }}$ Rs. 100 for weddings (if the wedding is of the offspring of a sibling or husband's sibling, the gifts of a bride may cost Rs. 10oo, including a pair of clothes for her trunk (de sundak jora), a sazar, and shoes). A maid may also give the same amounts for the birth of a relative's child, and at illness she may take a litre of milk, eggs, or a chicken. The amount a maid has received from her own relative will be reciprocated with an increase of Rs. 5 (surcharges on gifts are levied to save the face of the original recipient, or zan kooz na khkara kai). In contrast, those unable to offer anything but their person participate marginally in society, and are visited only by a small circle of close kin. ${ }^{28}$ While in practice Bibiane send money and food to villagers and maids' houses during their gham-khadi without visiting them, gham-khadi is understood to impose mutual, though asymmetrical, obligations. For instance, when one 24 year-old maid's father died in Swat, her 3 o year-old Bibi sent the maid's mother Rs. 5 ooo from Islamabad; several months later when the maid's mother came to visit her daughter's Bibi, she brought two chickens (costing Rs. $5^{\mathrm{O}}$ each), and on another occasion a dozen eggs (Rs. 3 each). Maids widely report that their state of poverty makes them na-chara (unable) to undertake expenditure beyond their means. Reciprocity that involves gham-khadi money in figures of Rs. 1000 and Rs. 2000 is 'droon kaar' (heavy work), meaning it is beyond their means (char) and befitting only Bibiane.

${ }^{28}$ Similarly, a maid, SherAfzoon (aged about 6o) explained the reciprocal nature of gham-khadi among poorer Pukhtuns: 'no one does my tapos (enquiry) because I am poor (ghariba). I cannot afford to do gham-khadi(i.e. give money)', unlike many villagers, she said, she refuses to take loans to do gham-khadi. 
Widely stated comments thus indicate that people make ghamkhadi contributions according to their means. While the gham-khadi of Bibiane and maids is lopsided, that between Bibiane should ideally be characterized by reciprocity. Given that each family maintains gham-khadi relationships with a large number of women in other families, Bibiane who receive gham-khadi money collect considerable sums. The cash may be earmarked for feast money for weddings and deaths, or used for personal purposes. Bibiane say that the money given to women belongs to them; what they do with it is, in one Bibi's words, 'women's business'. One Bibi revealed that in total she received $2 \frac{1}{2}$ lakh rupees (approx. £2,631) for her two sons' births which she invested in the stock market. Several other mothers bought expensive gold jewellery with the money, purchasing new 'sets' (necklace and earrings) for future khadi events. Mothers with baby daughters said that the jewellery represented a long-term investment in their daughters' dowry (compare Ward 1997).

While some Bibiane benefit financially in the short term from ghamkhadi, the deferred nature of reciprocity means that ceremonies' cash requirements place large, unpredictable demands on the household incomes managed by Bibiane. Many revealed that they spent a large sum of the house pay (de kor kharcha) on gham-khadi; and some Bibiane stated their reliance on their own sources of income. One Bibi reported that, as a young bride, she was too shy to ask her husband for the necessary cash and 'senselessly' (kam-aqltob) sold her gold jewellery to pay her close kin's gham-khadi money. Yet as Bibiane get older and more powerful within their marital households, their duty to be munificent in gham-khadi proportionately increases. Many Bibiane (young and middle-aged) argued that both Islam and Pukhto conventions give women a right to her husband's wealth, whereas her own income is her own. In one Bibi's words, 'I can save it; I can spend it; I can do anything with it'. Moreover, comments were made suggesting that men would consider themselves ashamed to be supported by their wife's income, as a professionally employed Bibi Arifa, a nonPukhtun wife from Karachi married for eighteen years to a Mardan Khan, remarked: 'A Pukhtun man would not have his wife spending her money on the household to throw in his face and say: 'Oh, I'm supporting the family'. No way, he would go that extra mile to make sure his money is spent.' The reciprocity implicit in the practice of gham-khadi gives it affinities with characteristically Pukhtun forms of exchange, badal; analogous to badal in another sense-that of revenge (Baal 1975: 11; and see Grima 1998: 5, 70-72 on the reciprocal 
structuring of revenge). Just as men seek payment from those who have insulted their honour, so women exact vengeance for social slights and neglect (particularly in cases of inter-family land dispute) by selectively observing the obligations of gham-khadi. ${ }^{29} \mathrm{I}$ have described reciprocity as a non-negotiable obligation, but it may in fact also be refused by Bibiane's deliberate choice. In one instance, an Islamabad Bibi referring to her second cousin told me: 'Zurina's son is born [in Islamabad], but she didn't come for my 21 year-old niece's tapos [enquiry visit] when my niece was diagnosed with cancer. So I didn't go for her son's birth ombaraki, even though my daughter is named after her.' In this way, much of the otherwise suppressed and deflected hostility between female affinal and kin relations is expressed through reciprocation and non-reciprocation in gham-khadi. In terms of how reciprocal obligations are discharged, wide scope exists for individual moral choices, as perceived offences and antagonisms work themselves to the surface in voluntary actions.

In this sense of female choice, Bibiane's control over a family's gham-khadi relationships may be more typical of elite than non-elite families. Amongst the poorer Pukhtuns who tilled farmlands in Chak Shehzad near Islamabad as tenants of Pukhtun Bibiane, men typically exercised greater direction over their wives' gham-khadi relations. The wife of one zamindar (farmer) stated: 'We have this rewaj (custom) that if my husband doesn't get along with anyone, including my family, then I and my children avoid those people. But if the dispute is between me and another person then my husband will not break relationships with them. Men have more ikhtiar (authority); women don't, because we live in such gharibi (poverty).' Unlike the range of many poorer women's positions in the family, Bibiane and even some of their husbands admitted that in upper social echelons men eventually follow their wives' lead in avoiding kin. With her affines, the case is more complicated and varied; husbands may here behave with a degree of independence in maintaining personal relationships with their own mother or sister. Yet during the time of my fieldwork, there were more than two cases where relations with mens' mothers and sisters were entirely severed for extended periods through their wives' disputes with them. The machinations of family politics seem more involved amongst Khan families, where the connections between people are

${ }^{29}$ Among the Pukhtuns I interviewed there were more than forty inter-family land disputes of daughters against mothers and in another case father; sisters against brothers; and patrilineal cousins against each other. 
more multiple, and forms of dependence not officially governed by money or retainership.

\section{Obligation and Preference: the 'Burden' of Performing Gham-Khadi}

Bibiane's actual gham-khadi practices show receptivity to some degree of choice. Bibiane actively discriminate how much gham-khadi to do, how immediate one's family gham-khadi circle should be, how to prioritise double engagements, and even whether to abandon social relations with families altogether. Yet the choice of whether to do or not to do gham-khadi is limited. The obligatory nature of ghamkhadi is widely perceived as binding and burdensome as it constrains as well as shapes social visiting among women. 'Gham-khadi is a boj (burden) because women want to visit each other, but there are all these rules of "give and take" which restrain them' expressed Nasreen, a 22 year-old dai's granddaughter, employed as a 'Lady Social Worker' (visiting women's houses as a government employee in Swati villages with medicine and contraceptives). The gham-khadi visitor, regardless of social status, must give on arrival to avoid the appearance of dishonour (sharam). Likewise, full hospitality must be displayed to avoid damaging the host's social reputation. As one convent Bibi, originally from Mardan in her late forties, now living in Islamabad, remarked:

If you do gham-khadi you can't go empty handed. That's not our way. To help in that khairat (charity meal) you have to take something-money (paisay), gift (thofa), rice (wreeje), oil (ghwaree), and sugar (cheenee). With inflation, it is a financial burden and then we can't keep it up because nobody has the time. The performance of gham-khadi should not be prolonged (over a period of days). But if you don't do gham-khadi, people get very offended.

Another Bibi, in her thirties, originally from Swat but living in Islamabad, amplified this point in English: 'Gham-khadi kills everybody, rich and poor. If you don't do it, people say, "she's an outcast". They will boycott her socially; because, they say, she hasn't done it with us ... but once you start doing it, there is no end.' The impasse expressed by these Bibiane is one felt across class, gender and region. For instance, a middle-aged village woman associated with an elite household (rumoured to be the Khan's mistress) said following a week 
of several kin gham-khadi events that she had been obliged to gift large amounts of rice, oil and flour in the village:

The boj (burden) of gham-khadi is on our kakarai (skulls). So in this age we're fed up (dertang) with gham-khadi! Gham-khadi has burdened us greatly. Because if we do not do it-it is sharam (a great shame). It takes the clothes from off our backs (lit: I have been skinned for this: sarman me wakhatha). It's a burden, because gham-khadi never ends and the [network of] people is vast, while our incomes are comparatively small. If we don't do it, people say they don't understand rewaj (custom); if we do it, we pay out more than we get in. Oh, God! My heart is fed up with this gham-khadi.

As reflected in the words of this outspoken woman, Bibiane also entertain a range of spirited views about gham-khadi and the burdens it places on them.

Such views are possible because gham-khadi is felt to be obligatory by Bibiane, yet it is not always welcomed or liked. Many Bibiane insisted on the invariant nature of the forms and orders of procedure acceptable in gham-khadi. Visiting excludes, or forecloses upon, spontaneity, since visits follow conventional patterns. The greater the intricacy of Bibiane's kinship ties, the more gham-khadi there is, and the more arduous it becomes. The difficulty, intensity and frequency of gham-khadi visits lead to Bibiane and other Pukhtun descriptions of gham-khadi as a 'boj' (burden) or a 'musibath' (problem). ${ }^{30}$ The boj is one that is seen to extend from the social to the core of familial life.

In relation to childcare, Bibiane experience great levels of distress over how their children's requirements, particularly schooling, might accommodate constant interruption by mothers' gham-khadi. Arifa told me, 'Every time there is a death in my in-laws', I have to leave everything in Islamabad and go to the village. But I cannot take my children with me, as they will then miss three days of school'. In one case of an aunt-in-law's death, Arifa resolved her dilemma by requesting an Islamabad friend to nanny her children. The demands made by ceremonies on mothers' time also detract from their childcare. Farah, in her late thirties, who studied at the Murree convent and works as an English-medium schoolteacher in Peshawar, told me (in the presence of her father and male cousins) that Pukhtun mothers of wealthy backgrounds spent more time buying and ordering clothes for gham-khadi, and attending ceremonies, than

${ }^{30}$ In other contexts, social scientists studying aspects of Western work have also described its nature as a form of 'burden' (Pahl 1989: 9), indeed making the kind of social work represented by gham-khadi as synonymous with "toil" (ibid: 11 ). 
they did reading with their children. Imitating the mothers, Farah gestured: 'No jee! there is a death here; a wedding there (Na jee! zama khwata mare sho; alta wada sho). Mothers are busy with gham-khadi; the father is tired, he comes home from office-the children are neglected and ignored'. Farah further gives an example of a student in her class:

Like, this little boy, who was beaten by his father. I called his mother to school and I said 'what happened?' She said, 'Oh, I wasn't at home, I had gone for my mother's brother's son's wedding'. The mother is never at home. The father comes home tired from office-he starts shouting at the children. There's no confidence at all in that child, and then they expect a good result!

Mothers hesitate to take their children to gham-khadi gatherings, since it involves a great deal of 'pasa kena' (standing and sitting) or meeting and greeting. Yet leaving them in the care of a maid arouses concern and 'sadness', in the words of one Bibi, as 'your children become insecure, clinging to you when you return home'. Both Pukhtun and Muslim mothers are idealised as devoted figures who bestow time and love on their offspring (kha moryane), yet the predominant Pukhto conception of womanhood paradoxically requires their absentation from the kor. This degree of onus on women leads some Bibiane to compare their customary conventions unfavourably with those of other ethno-linguistic groups in Pakistan. One Pukhtun Bibi said: 'Punjabian are better-they visit each other for short periods, raise their hands, pray, and go; but among Pukhtuns the formality is endless.' The latitude exercised by Bibiane in taking their children to gham-khadi or not, or travelling with their husbands, does not extend to negotiating non-attendance or forms of reciprocation in the absence of attendance. ${ }^{31}$ Bibiane are, thus, 'locked' into gham-khadi social behaviour.

\section{Participation and Exclusion: the Severing of Social Relations}

My exposition of obligatory relationships around gham-khadi gives substance to a concept of ceremonial performances as 'work', in the sense that work 'implements a rule'. My account situates gham-khadi

${ }^{31}$ Many mothers found the role of mothering and doing gham-khadi difficult to maintain. One young mother says, 'I breast-fed my son for two and a half years and during that time when there was gham-khadi I found it very difficult: as I could not leave him at home because he was attached to me. I had to take him everywhere with me, and feed him on demand. It was a very difficult time.' 
within the context of the social relationships which it sustains, seeking to determine what space it leaves for alternate modes of thought and action (non-participation, selective participation, the individuation of gifts and so on). Yet Bibiane are keenly aware of the high stakes of performing gham-khadi correctly. Omission, far from opening plural or less constrained social networks to non-participants, incurs a form of 'social death' (Bourdieu 1966: 217 ; see also Baal 1975: 11). As two Bibiane told me:

Asma: 'If you don't attend the wedding, then you have to come later for ombaraki. That is a very important part, because if you don't do that then all relations are broken...'

Yasmin: 'The people (concerned) get khapa [sad] from [i.e. angry at] the person who did not attend. People say, "(s/he) didn't come for our death or wedding!" ('Wai na marg la raghe na khadai la raghe!'). In death if you are absent, you have got to go for the dua afterwards. Because if you don't do either one of these, the ombaraki or the dua, people won't do it with you!'

More specifically in funerals, those who miss the important days are not invited to the Fortieth day commemoration, and are subtly shunned in social gatherings.

The following incident indicates the importance of attending both gham and khadi. Samina Bibi (aged about 48) is from a wealthy and prestigious household from Swat. She teaches, works, and lives in Islamabad with her non-Pukhtun husband (from a Nawab family of Indian origin based in Lahore). Samina injured her back, which caused her to miss her second cousin's daughter's wedding. She told me: 'I stayed back. I didn't want to go to the wedding in Swat. My [older male] cousin told me: "If you do not do gham-khadi no one will come to you either and you'll die a lonely woman with no one by your graveside." Compliance is thus enforced not only through the prospect of unfortunate consequences, but more directly, through the urgings of close relatives. ${ }^{32}$ There is nothing uncommon in someone taking it on themselves to upbraid another for their errors. Such a formula of 'commanding right and forbidding wrong' is often observed in Pukhtun contexts in interpretations of Islam, becoming an arena for conflict in Al-Huda's application of literal scripture.

${ }^{32}$ Analogously, Foucault in Discipline and Punish (1991) describes the constitution of power in the modern era as being a matter of the 'molecular' interactions of individuals insofar as they exert normative expectations (regarding custom or morality) on each other. On Foucault, see also Nola 1998. 
Looking at non-compliance from the reverse perspective, that of snubbed Bibiane, absence from gham-khadi causes serious offence. When I accompanied a group of Bibiane to visit their niece, Parveen, in Islamabad on a congratulatory birth visit (ombaraki) for her first-born baby girl, Parveen (married to a Mardan Khan and originally Swati) complained that her mother-in-law and sister-in-laws had failed to perform her ombaraki, although her baby was born after several years of marriage and was thus eagerly anticipated. An earlier property dispute had led to mutual avoidance in gham-khadi, even though the events were often shared. Referring to her mother-in-law, Parveen said: 'it is also her happiness, but she doesn't understand (kho poyegee $n a)$.' Looking tenderly at her crying baby girl, she added: 'She reminds me of my mother-in-law when she looks angrily at me.'

A families' prioritizing of certain engagements over others may also cause relational problems. In one case, a Bibi's husband's female cousins neglected to visit her hospitalized husband a month after his operation, while they travelled to a remote village for another cousin's dai's (wet-nurse's) husband's death. Shehnaz, the snubbed Bibi, cried: 'if they don't care about us, why should we care about them! Illness is the time when all relatives come together (khpal ratol shee).' She declared, 'I am not going to do any more ghamkhadi with them!' These simmering resentments are rarely vented in direct confrontation (rishtinee), which, one Bibi told me, 'is very rude' (compare Pitt-Rivers 1966: 40). I was present during a number of different Bibiane's rishtinee, where the most common response was 'munkaredal' (to deny or reject) or evasion, especially in response to accusations of intentional wound or insult.

Disputes among Bibiane escalate from neglect of the customary 'salaam, ${ }^{33}$ usually accompanied by an embrace and a kiss on either cheek, to coldness and discreet avoidance, and finally to outright and widely understood aversion altogether (in a badal). The confusion over whether a festivity is missed for genuine reasons or in retaliation, provokes much anxiety for Bibiane. As gham-khadi contexts are segregated public spaces, 'the constant concern over "seeing" who sees whom, when and where' (Gilsenan 1990: 190) becomes of crucial importance. Relatedly, 'not being seen', or to avoid another's ghamkhadi intentionally in an act of subversion, is also a characteristic feature of Pukhtun social life.

33 'There is nothing worse than to pass unnoticed: thus, not to salute someone is to treat him [or her] like a thing, an animal...' (Bourdieu 1991: 11). 


\section{Juggling Professional Work, Housework, and the Work of Life}

Gham-khadi places multiple and competing demands on women's time, energy and responsibilities in their roles as mothers and wives (in their kor-kaar: housework), kinswomen (their zeest-rozgar or gham-khadi) and professional employees (their kaar-rozgar). As the near-exclusive form of female adult sociality, gham-khadi and tlal-ratlal prohibited women from any form of employment outside the kor. Women (and men) give moral precedence to zeest-rozgar or gham-khadi, as they define Pukhtun ethnic identity and provide a particular philosophy of life. The imperative of maintaining social bonds overrides both childcare, as we have seen, and housework in the sense of Bibiane's supervision of menial tasks. The tlal-ratlal requirements of spontaneous hosting often oblige Bibiane to be in two places at the same time, sitting with the guests and providing tea and food. One Bibi whose maid had gone on holiday stated, 'if I receive guests I have to sit with them-to leave them is said to be badtameezee (impolite).'

The requirement on Bibiane to host gham-khadi sits uneasily with some women's perception of their household roles and instincts. One 35 year-old Swati Bibi, resident in Islamabad and married to a Mardan Khan, argued: 'I think when a woman has a baby, then people should not even visit for the first three months. When my son was born, some people apologized for coming so late, but in my heart I said "shukkar $d e$ " (thank goodness), because receiving and entertaining guests the way we do is difficult when your hands are fully occupied.' The task of hosting, particularly in Islamabad where Bibiane's gham-khadi networks vastly increase, is broadly but secretly seen as an unwelcome pressure, as in the words of a Bibi:

Entertaining guests is like a tug of war-having a family, keeping a house, and doing gham-khadi all at the same time. Nothing is relaxed or enjoyable now. You have to be obliged. You have to be there for your children's needs, for the needs of gham-khadi and society, for your husband's needs, your in-law's needs. So it's always needy, needy of a woman, and a woman's own needs are ignored.

It is difficult to convey an appropriately multilayered sense of how arduous a Bibi's work of directing household labour can seem to the women involved. In the local context, the maids on whom Bibiane's social reputation depends are often illiterate, untrained, unused to electrical appliances (microwaves and electric lighting), and unversed in the scrupulous differentiations of hosting practices. Bibiane's 
labour, although partially physical, requires constant thought and watchfulness, particularly in negotiating differences of propriety across locations and classes. Maids, in their Barthian capacity as independent 'players', may make increasing demands for gifts and privileges, and Bibiane do not feel able to 'call their bluff' and drop zeest-rozgar responsibilities entirely. During my entire fieldwork period, I knew of only one Bibi, Shandana, who explicitly chose not to employ maids for childcare, and looked after her six children herself, even at the cost of avoiding gham-khadi. Once Shandana's children were old enough for full-time education, she returned to gham-khadi participation, though only among a small circle of close family, cousins and friends. The additional time afforded her, enviably to some, with her limited gham-khadi responsibilities allows Shandana to serve in organisational contexts, such as the monthly meetings, lunches, and exhibitions of the All-Pakistan Women's Association.

Some Bibiane juggle the customary obligations of gham-khadi with professional work (kaar-rozgar). Khanan often avoid marriage to highly educated, professional career women because careers are held to distract from childcare and house management (see also Alavi 1991: 130). Even the tlal-ratlal displacement that characterises gham-khadi poses enormous obstacles for Bibiane wishing to take on full-time work. Bibiane often indicated that these gham-khadi demands proved insuperable. Zara, a 55 year-old living in Islamabad, described in English that she was forced to give up teaching 'because of gham-khadi. When my father's brother died, I actually went to the kille (village) for one night only! But even one night meant I missed two days of teaching my school children.' Even this highly unconventional pareddown version of gham-khadi attendance left Zara feeling that she had violated proper standards of professional conduct.

Although Bibiane may wish to determine their own future goals, they find many to be incompatible with gham-khadi. Yasmin Bibi, from Mardan, revealed her desire to take the one-year diploma course at Al-Huda International Institute of Islamic Education for Women in Islamabad. ${ }^{34}$ Although she perceived it a beneficial religious undertaking, the course would constrain her time for gham-khadi. Yasmin felt forced to discard her plan, stating, 'If I decide to do the

${ }^{34}$ Al-Huda awards diplomas to graduates of other universities after a year's study of the Quran and Hadith, however, its most popular classes are the open two-hour daily dars on the Quran during Ramadan, which have been attended by most Islamabad Bibiane. 
diploma at Al-Huda, I can't do gham-khadi; and if people know that I am in the country and I don't go for someone's death, the close relatives will never forgive me!' A more dramatic illustration of the strains caused by these conflicts can be seen in the case of Arifa. Arifa found her career as a United Nations development professional in Islamabad impeded by the demands of 'going and coming':

With some gham-khadi we had to go to villages in Mardan, like Shiva or Hoti where I did not know the people at all but with whom my in-laws did ghamkhadi. But then this is it. There is no question of 'not' going. My husband takes time off from his work. And I've been working since the second year of my marriage. But I 'had' to take time off. And that's one of the reasons I couldn't continue working in the U.N... [pause] ... I remember when my husband's aunt who was living in Mardan died in the afternoon. I was there in the middle of a Gender Training Programme. My husband said: '[Auntie] has died and they [her entire cohort of affines] are all leaving immediately for the funeral'.

While her husband initially supported the idea of his wife's employment, the couple's flexibility was limited through the equally conscientious Pukhto training inculcated in both husband and wife:

... I was thrown in a great dilemma. I was the lead trainer at the U.N. So what I did was I continued with my training. My husband (and the extended family) left for the village. He left the second car and the driver for me. My programme ended at 5 o'clock p.m. and then I left. But that was the only time I gave priority to my professional work. Otherwise, there were a number of times when I was in the middle of a project I had to just leave 'everything'!

Arifa's non-Pukhtun work colleagues could not appreciate her required absences, nor evolve some form of flexibility allowing her to work more intermittently. She describes another occasion:

My sister-in-law's daughter's husband died in Bannu. In the morning I had to go to the office-I was working for UNICEF at that time and was waiting for a mission that was here from Philippines, but again I just 'had' to go. What did I do? I attended the meeting half way through, and then again I went with the driver whereas the whole family left early all the way to Bannu [six hours' drive from Islamabad] for two nights. But I 'had' to go. There is no way I could say: 'I am a working or career woman, and I may come the next day'. No! You had to show your face there!

The conflicts between work schedules and gham-khadi responsibilities (felt also by employed husbands) have led Bibiane such as Zara and Arifa to negotiate a space, both physically and symbolically, for Pukhtun self-representations and practice within the world of work. Arifa gave up her U.N. career, but opened a successful private primary 
school in half of her Islamabad house. The school and its garden are divided from the family portion of the house (both parts of which she personally owns). A wooden partition divides the garden, with parallel driveways and gates to the house. Within the house, a swinging door from the home-kitchen connects to the adjoining school. Arifa's maid makes tea and samose at her own home, and brings them over to the school for the visiting mothers of schoolchildren (some of whom are also her in-laws) and other guests. Thus, presence in her professional role at school does not preclude Arifa's performance of the norms of Pukhto, such as melmastia (hospitality), which remain incumbent on her as a Bibi.

\section{Rewaj and Islam: Dimensions of Personhood}

Morality in Muslim societies is the subject of a rich body of scholarly debate. ${ }^{35}$ However, it is often assumed that the central moral faculty aql (the power of moral discrimination, or social sense) in different Muslim societies is derived singularly from religious authority. Anthropologists of Muslim societies point to an 'Islamic theory of personhood' (Shalinsky 1986), which views humans as being endowed with two important faculties: aql, social reason acquired through discipline and education or $\mathrm{ilm}^{36}$; and the nafs or the human will and undisciplined impulses of the lower soul, which is contrasted with and controlled by the $a q l$. The properly instructed person has a developed sense of $a q l$, and thus seeks to act with propriety (adab) at all times. Nafs uncontrolled by aql creates fitna (disorder). Some anthropologists claim to have taken Muslim societies at their word in according a greater capacity of $a q l$ to men than to their female kin or counterparts (see Shalinsky 1986; Torab 1996; Metcalf, B. D. 1986).

Bibiane's use of the term aql, however, to denote thoughtfulness, cognition and an engaged attention in relation to social procedures,

35 On morality and $a q l$, 'the faculty of moral discrimination' see Metcalf, B. D. 1984 (a): 10; 1984(b); and Kurin 1984, Nancy Tapper translates aql as 'responsibility' (1991: 15, 209), the following authors as 'social reason' or 'sense'; see Abu-Lughod 1986: 90-91; Anderson,J. W. 1985; Ewing 1988: 8; Marsden 2002: 76 ; Metcalf, B. D. 1990: 8; Shalinski 1986: 325 , Torab 1996: 236. In the context of South Asian Islam, Ewing notes: 'guidance by 'aql bring[s] one closer to God, and also higher on the social scale.' (Ewing 1988: 8).

${ }^{36}$ Of the Quran, hadith, and shari'a which provides a guide for living correctly in this world (Shalinsky 1986: 325 ). 
suggests a greater plurality of the concept. Different senses of aql are deployed to refer to religious observance and social self-possession or rationality. In practice, these different uses are contradictory, though social agents manifest both. Bibiane envision their actions in ceremonies as being highly deliberate, while their self-conception is a matter of both 'Muslim' and 'Pukhtun' identifications. While the Western media often portray (in the wake of the recent rout of the Taliban) Pukhtun life and thought as extremist and monolithic Islam, ${ }^{37}$ many educated young Pukhtun Bibiane consider Pukhto and Islamic practices to be in certain ways antithetical. These Bibiane experience a continual tension between the aql of rewaj (custom) or Pukhtunwali, and the aql of mazhab (religion) or Islam. The religion thought to encompass every aspect of Muslims' life (see Gilmartin and Lawrence 2000: 1) has been problematically construed by some Bibiane as proscribing certain gham-khadi rituals.

The idea of aql is integrated into the (self-)representation of distinctively Pukhto values in a nuanced fashion. People who perform gham-khadi well, maintaining relations of tlal-ratlal (going and coming) with a wide social circle on all the significant gham-khadi events, are said to be persons who 'know' and 'understand' (poyegee) Pukhto. In other words, they possess a degree of social aql that has been cultivated through experience, time (wakht), and age (umar). Elders or masharan of both sexes may be described as 'aqalmand banyadaman' (persons of $a q l$ ); they are shown great respect in gham-khadi events, and their participation consecrates observances as socially significant. At the other end of the age spectrum, children are widely referred to as 'kam-aql' or 'be-aql', or persons with little or no aql, disqualifying them from a full role in gham-khadi events. While girls may attend with their mothers, they have no formal obligations in gifting, attending, or in offering congratulations or condolences. Between elders and children lies a wide range of persons who may or may not have cultivated different levels and degrees of $a q l$. Aql, as developed in a person's gham-khadi performances, influences others' wider moral evaluation of that person's 'khawale' (goodness).

Bibiane's judgments of individual gham-khadi performances are supremely important in evaluations of persons' character and status, not only in morality but also in social skill. In conversation, ' $k h a$ ' (good) people, those supposedly diligent in gham-khadi, are contrasted with

${ }^{37}$ Richard Tapper argues 'there is no simple equation Taliban $=$ Pashtun $=$ Islam = terrorism’ (2001: 13). 
others who omitted attendance in the past. Such belittling of women's social $a q l$ works as a disciplining technique, however humorously it is expressed, reaffirming family relationships and household hierarchies. People falling short of prompt reciprocity in gham-khadi practices are referred to as bad (literally, bad), na poyegee (lacking understanding), lewanai (mad), or maghroora (proud). In contrast, "Khogmun people" (responsive to another's hurt) perform gham-khadi out of sensitivity and respect. Others often comment about these khogmun people. A statement I widely heard was: 'Bibi and Khan are "good" $(k h a)$ : they do our tapos (enquiry visit)'. Bibi Gul, referring to her deceased paternal uncle, remembers: 'Kaka was a very good man: he did everyone's gham-khadi and so many people came to his funeral. His children are just like him. When my young son had a heart operation, Kaka's sons and daughters were the first to come for tapos.' Diligent familial attendance at ceremonies absolves young Khanan, in particular, of the accusation of headstrongness or selfishness. Those present every day at commemorations (including the Fortieth and year) are said to show a greater understanding of Pukhto, and thus a greater social sense. Yet the judgment of a person's morality in their performance of gham-khadi creates confusion for many young Bibiane, due to their purist understandings of Islamic hadith.

Al-Huda graduates of the word-by-word Quranic exegesis and of the Fahm-al-Quran program during Ramadan are increasingly returning to the village-context, seeking to modify Pukhtun practices. Bibiane with diplomas from the Institute see themselves as emerging with a far deeper understanding of the Quran and hadith (the basis of Islam) both in philological terms and as a living practice, than is prevalent in Pukhtun society generally. Bibiane's grasp of the meaning of the scriptures may especially be contrasted with that promulgated by the mullahs, who, in Pakistan, are typically summoned to wealthier persons' houses to teach children the Quran by rote in Arabic. AlHuda is distinctive and novel in the Pukhtun context in that highly educated women interpret religion for a female audience. At the time of my fieldwork, much debate and interest developed around the women's Al-Huda courses and dars classes primarily taught by the organization's founder, Dr. Farhat Hashmi (who took a Ph.D. from Glasgow University), among a wide array of Bibiane, and among other women from multiethnic backgrounds in Islamabad.

Within the context of Al-Huda lectures themselves, conventional gham-khadi practices are referred to critically as 'rewaj' in Urdu, or 'customs' in English. Al-Huda's exegesis and commentary upon the 
sacred Islamic texts (the Quran and hadith) implicitly disputes the conformity to religion of customary gham-khadi life-cycle events. While Pukhtun Bibiane mark funerals by collectively commemorating for forty days after burial, the salwekhtamma, and a year, the kaal (even for two years), the Prophet (PBUH) prohibits Muslims from mourning any deceased other than a husband for longer than three days (Sahih Bukhari 1994: 324 [ch.14:65o]; see also Yusuf 1989 [Quran] 2: 234). Again, Pukhtun families celebrate marriages for over three days, while Al-Huda Bibiane say that the hadith refers only to two events: the Nikah and Walima (making no mention of the Nakreeza or 'Henna day', celebrated by dancing and singing). The Pukhto forms of gham-khadi and what might be expected of an Islamic pattern of observance, while not antithetically organized, depart from each other at significant points.

Bibiane who attend Al-Huda classes necessarily become aware of the contradictions between Islam and Pukhto, allowing them vocally to express their disapproval in Frontier villages. There are two means by which the women express their dissent: in speech, 'forbidding wrong' at or after gham-khadi gatherings, or (more commonly) in choosing not to attend on particular days. One Bibi who had gained a diploma at Al-Huda refused to commemorate the traditional Fortieth day after a particular death. Describing her explanation to her would-be host, she stated: 'Khorai (sister), please don't be sad, but I cannot come because I don't perform the Fortieth any more'. On different occasions, a few Bibiane absented themselves from the Nakreeze.

In exercising this power of religious discrimination, Dr. Hashmi's students have in effect taken up a challenge to 'command right and forbid wrong' in local village contexts. As graduates, they conscientiously translate Quranic Arabic into the local languages of Urdu, English, and Pukhto. Several Bibiane now give daily Quranic classes in their houses in Swat, Mardan, and Islamabad, bringing together small groups of local women and children (of up to 6o persons) daily or weekly. In 2003, a group of Bibiane established a satellite institution in a Mardan kille-kor, instructing village-women in Pukhto. Dr. Hashmi herself has been invited to the Frontier on a number of small khadi occasions, once giving a talk during the Quran khattam (completion) ceremony of a child of the Toru Nawab Family. Her courses seem continually to be gaining popularity amongst Bibiane specifically and Pakistani women more generally: in 2000, she relocated to Karachi, and reputedly draws more than five hundred women to the Marriott Hotel hall, with many turned away. Islamic 
scholarly learning bestows authority on its possessor regardless of age, gender or socio-ethnic background (compare Cook 2000: 528): a Prophetic teaching states: 'the ink of the scholar is more sacred than the blood of the martyr'. The involvement of elite and middleclass Pakistani women in Al-Huda creates a coordinated network of instruction spanning rural Pakistan from Swat in the north to Karachi in the south. Students at these classes may be wealthy family-members of politicians, businessmen or diplomats or poor village-women. In principle, all women gain equal merit through attendance and study.

The reforming spirit of Al-Huda-educated Bibiane is comparable to the arguments deployed by the late nineteenth-century north Indian Deoband movement that claimed women's ceremonial 'customs' for marriages and funerals were gunah (sinful) in the absence of a Quranic basis. ${ }^{38}$ Maulana Ashraf Ali Thanawi (1864-1943), one leader of the Deoband movement, defines an entire female curriculum of 'proper' education in his book Bihishti Zewar (Heavenly Ornaments) (1905). According to the Bihishti Zewar, female accomplishments range from the alphabet to styles of letter writing, polite conversation, recipes, managing household funds, and religious observances. In particular, book 6 focuses on women's activities at life-cycle events. While written for the 'wellborn' and 'grand ladies' (Metcalf 1990: 25, 110), the Bihishti Zewar became widely popular with the Muslim women of the sub-continent. Thanawi's text is particularly significant due to its translation into many languages, including Pukhto (ibid: 26) the language of the Pukhtun people, encouraging women to reject, in theory at least, gham-khadi customs. ${ }^{39}$ This effort of regulation bequeathed nineteenth-century Muslim women a religious identityas seekers of the 'jewels of heaven', and half 'ulama' or religious clerics-even as it contested the Anglicisation of elite society in the

${ }^{38}$ On the Islamist critique of taqlid (blind imitation of customs and traditions) in Egypt in discourses of proper pedagogy for children and mothers, see Shakry, 1998. Compare Gilmartin and Lawrence (2000: 1).

39 Abu-Lughod writes, 'Thanawi will empower women with literacy but relegate them to a newly created private sphere where they can even develop some modern forms of housewifery ( ... weights and measures ...).' (1998a: 19). Thanawi, ironically, describes each customary practice entailed in life-cycle events among Muslim women of the sub-continent as 'the false shari'at that thwarts proper order [Islamic law]' (Metcalf, B. D. 1990: 3) as it entails, he argues, extravagance, indulgence, and license: 'It is evil to consider something required that is not so specified in the shari'at' (ibid: ${ }_{15} 8$ ). This is, he argues, to invent new traditions thus bid'at 'reprehensible innovation that is the negative counterpart of the sunna towards which the shari'at leads.' (ibid: $\left.3^{1}\right)$. 
imperial era (see Devji 1994). Echoes of such ideas have actually been expressed by certain sections of elite Pukhtun society itself. For example, the ruler of Swat, Badshah Sahib, in his account of The Story of Swat writes:

Many an absurd custom on the occasions of marriage and death was prevalent in the State. People incurred huge expenditure, much above their means or status, and involved themselves in serious monetary difficulties. I abolished all such practices and decreed that ceremonies should in future be held modestly and inostentatiously. Women folk were restored to their rightful place in society, and were given the rights and privileges in the Shariat ...In short, I spared no effort in weeding out all moral and social evils (Wadud 1962: 115 ).

Whether the people of Swat celebrated gham-khadi modestly after Badshah Sahib came to power remains undocumented. My own research into contemporary practices indicates that gham-khadi remains ingrained in Pukhtun society. Yet without necessarily referencing the Deoband intervention, the Al-Huda Bibiane-some of whom are the descendants of Badshah Sahib and the Sufi saint, the Akhund of Swat-are, in a more female-centred language, contesting and negotiating 'custom' through life-cycle events. ${ }^{40}$

Many Frontier Bibiane living in Islamabad spoke of the transformation Al-Huda has brought to their life and spiritual practices. Bano Bibi from Swat remarked:

Before Al-Huda we were doing the traditional purdah: for example, we would observe purdah from men in the village but not in Islamabad; we would remain bareheaded in front of some na-mahram men (marriageable) men like our brothers-in-law and not others. Now, Mashallah, I am trying to avoid that and be consistent. I am trying my best to do everything Islamic.

Visible changes show in Bibiane's dress, as well as in their enactment of gham-khadi. Participation in dars entitles Bibiane to leave their houses under religious auspices, wearing a hijab and loopata (veil). Young married and also unmarried Bibiane may leave the kor for religious destinations. The increasing prevalence of the hijab attracts both approval and criticism from other Bibiane. For one conventeducated Bibi in her late thirties, who had been wearing the hijab for

${ }^{40}$ One of the Akhund's descendants was Bandai Bibi, a female saint (compare Smith 1994). Sherani observes that 'the pir has dominated the whole countryside since the advent of Islam.' Strikingly Bibiane, as descendents of a Sufi saint are now beginning to take up harder-line Deobandi-type Islam. 
seven years after moving to Islamabad:

Some people think being 'modern' is to wear sleeveless kameezes, have the latest hair-do, go for parties, drink sharab (alcohol) and talk in English. But if someone, like me with a hijab, is in that party, they'll ignore me. People tell me, 'are you crazy wearing the hijab; you're a Fundo (a fundamentalist)' [She fixes her hijab]. Pakistan is a Muslim country, and covering your hair is the first identity of a Muslim woman, yet people here never fail to ask me why I wear a hijab.

Many Al-Huda graduates impose higher moral standards on themselves, although their right to Muslim authority is contested or seen as problematic in different contexts. Young women's arrogation of Islamic prerogative as having priority over customary privileges, especially, is often vexed, leading to conflicts within families. In one instance in 2004, a sixteen-year old daughter, who recently adopted the hijab and attends Al-Huda, reputedly cited Islamic prohibitions in refusing to be kissed on her forehead (as customary in some Pukhtun families) by her visiting 'uncle', or the male cousin of her father. Her father took offence, construing her action as a rebuff to his authority and an outrage to Pukhtun hospitality. However, in effect, the ambiguous relationship between scriptural precedent and everyday Pukhto allows most Bibiane from day to day to reconcile opposing values and plural personal inclinations and identifications. ${ }^{41}$ Scholars focusing on South Asian Islam have noted this ambiguity whereby Islamic law (Shari'at) is given 'unconditional theoretical acknowledgement' without being enforced in practice (Ewing 1988: 7; compare Chhachhi 1994: 82).

Differences of outlook between Al-Huda and non-Al-Huda Bibiane are more usually accommodated into gossip and tacit forms of contrariety, than explored in debate or rishtinee. A number of Bibiane, of various ages and educational backgrounds, dismiss hijab-wearing relatives 'behind their backs' as 'narrow-minded hypocrites'. For them, cousins or sisters-in-law's adoption of Islam tends to represent another strategy of rivals to win social pre-eminence or personal esteem. One Bibi said, in English, that her hijab-wearing cousins 'push religion down our throats'. Yet knowing more about Islam than their husbands, older Pukhtun women, kin and affines, enables middle-aged

${ }^{41}$ In the Jain context, Laidlaw describes personhood in a field of cultural multiplicity, not as 'a stable coherent self' but rather as something " distributed"... This gives us the notion of a self which may be divided against itself, an assemblage of possibly conflicting "subject positions'." (1995: 20). 
and younger Bibiane to transcend 'patriarchal' and social norms by referring to the higher moral order of the Quran and hadith. Bibiane command much authority in their Frontier village-houses. Many Muslims are illiterate and cannot read the Quran (Eickelman 1992: 644); even some western-educated Khanan (sent abroad for school at early ages) cannot read the Arabic script. Convent-educated Bibiane are literate in Urdu and thus see themselves as well-placed to become the reformers and teachers of Islam (compare Horvatich 1994: 81 2; and Turner 2000: 94). Moreover, women exercise power as the orchestrators of the 'women's work' of gham-khadi, where changes in the form of observance are binding on both sexes. In this way, women's centrality in the ceremonial continuity of Pukhtun society grants them particular leverage for defining the terms of gham-khadi-although in partial and contested ways.

\section{Conclusion}

In this article, I have explored the ways in which some Bibiane are beginning to exploit uncertainties in Pukhtun definitions of work, morality, religion and Pukhtunwali, in order to better fit gham-khadi obligations to their own concerns (childcare, professional employment, personal friendships and antipathies, religious convictions). But it would be wrong to conceive of Bibiane, in terms of a 'theory of resistance', refusing their gham-khadi obligations within a wider 'patriarchal' society. Rather, customary practices in gham-khadi, as an especially important node of Pukhto, are successively refined through slight and incremental variants. These changes may be authorised by religion, by Western-inflected modernity or by reinterpretations of tradition. Their combined effect, in any event, influences Pukhtun social relationships as these are made and displayed through lifeevents. Whatever the dilemmas faced by educated Bibiane, most elite Pukhtuns continue with gham-khadi even when questions are raised over practicality or religious warrant. Within this context, an awareness of the contradictions in the work of gham-khadi is growing. Young educated Bibiane, unlike many of their husbands, broadly implement the Islamic challenge 'to command right and forbid wrong'. This is an important development, as Bibiane embody religious knowledge in the context of present-day gham-khadi.

This article has sought to explore Bibianes' performances of ghamkhadi as complex undertakings that engage the most fundamental, and fundamentally contradictory, ideas in Pukhtun experience. Through 
gham-khadi, women reinforce their social relationships through highly regulated procedures, understood as forms of work. The discourse of actors themselves reveals the term gham-khadi as both individual and collective, moral and potentially immoral, and voluntary and obligatory. Affines and other members of society evaluate each others' performances in terms of quality (immediacy of attendance, degree of mourning/celebration) and quantity (amount of money given, time spent at the event), while failure to participate incurs severed relationships and lost social respectability (ezat). Meanwhile, heightened consciousness of gham-khadi's partial incompatibilities with Islam, brought to the NWFP by Al-Huda graduates, leads to the incorporation of diverse or novel elements in the ceremonies themselves (see Ahmed, Amineh 2004). This small but influential group of Bibiane urge the reformation of practices impugning their sense of Muslim selfhood, and are met in turn by opposition from older and some middle-aged Bibiane.

The degree of paradox inherent in gham-khadi practices deepens its intractability in the lives of educated Bibiane. Bibiane may understand that gham-khadi obligations (visiting and house-purdah, 'tradition' and reform) are incoherent, yet this does not lessen their obligatoriness. Paradoxically, a central set of practices through which Bibiane are beginning to alter the terms of engagement with gham-khadi is that of textually sanctioned Islamic discipline. The prominent and productive role of educated women as instruments of Islamization in the Frontier contests many Western and local portrayals of Bibiane as pampered 'socialites' (BBC News: Ali, S. 2003), while associating Islam with poor young men, or the 'Taliban' (meaning students) (see Tapper, R. 2001). Bibiane's increasing, contestatory engagement with customary ghamkhadi is wrongly conceived within a feminist rhetoric of liberation from 'patriarchy' or 'tradition'. Plural forms of women's participation rather renew and bring complexity to ceremonies and social processes. The social continuity of Pukhtun ceremonial forms through time, and the social solidarity of Pukhtun society, are thus not necessarily damaged by Bibiane's ongoing reinterpretation of the 'work of life'.

What is at stake for a Pukhtun Bibi who does not perform gham-khadi at all or inappropriately, is her personhood as publicly conceived-that is, her reputation or ezat. Due to purdah, a Bibi's ezat represents the only aspect of her personhood that circulates freely in all public contexts, and its cheapening (by her failure to perform adequately) impairs her social status. Criteria of gham-khadi performance are thus tied to individuals' sustained ethnic identity (Tapper, N. 1991: 107). In this sense, 
behaviours presumed antithetical to ezat-miserliness, failure to perform or return gham-khadi visits, inadequate gifts, unseemly emotion, and confrontation (rishtinee) — detract from a person's embodiment of Pukhto. On the level of collective representation, the nonconformity of wedding or funeral procedures with social expectations renders those procedures socially inadmissible, vexatiously 'half-done' or nonexistent for close family members.

Another especially interesting dimension of female ceremonial performance is its linkage with male political power. While many Khanan were hesitant to attribute any extra-domestic influence on a woman's skill at gham-khadi, both women and men suggested that the standing of a Bibi's family, including her husband's political fortunes, does depend on this proficiency. In this sense, my discussion of Pukhtun gham-khadi illuminates an area of women's activity not covered by Nancy Tapper's account about Iranian women's formalized visiting khayr-u-sharr. Tapper presupposes that women engage in hospitality, prestige- and position-building to the extent that they are excluded from male public life; she claims that their networks rarely overlap with male circuits of patronage and clientage. Yet I suggest that ghamkhadi is continuous with male politicking, not parallel to it. What might be considered political power within a political anthropology of Pukhtun society is denoted as the possession of honour (Abu-Lughod 1986: 97) in this context. 'Power, properly developed, enhances izzat [ezat]; izzat legitimates power' (Mandelbaum 1993: 22).

The pioneer works of Pukhtun anthropology were couched in a political idiom, understanding social activities as strategies oriented towards Khans' 'maximization' (Barth 1986) of political power. I have offered another perspective, suggesting that tlal-ratlal visiting might be better conceptualized within a horizon of social phenomena. In satisfying the crowds of female onlookers at weddings and funerals, Bibiane establish a store of social capital partly constituted by their personal ezat. For Bourdieu, in his work on the Kabyle the societal forms of 'symbolic capital' (1991: 180) (as in the effects of gham-khadi: its feasts, gatherings and clothes), and its forms of 'economic capital' (ibid: 195) (Khan patrimonial wealth) are ultimately exchangeable or subject to equivalence. In these terms, the lavish expenditure among Khan families on wedding and funeral hospitality would represent the consolidation of familial inheritance through the maintenance of ultimately renumerative social relationships. While Bourdieu considers some forms of display as 'wastage' (of social energy; ibid), people's participation in gham-khadi remains rational 
insofar as they serve their political interests. Such a rationalization of gham-khadi, however, fails to deal with the intricate network of zeest-rozgar relationships on their own terms. It is the particular social and familial connection, no matter how distant, not the primacy of identification with a political class, that is important for Bibiane in attending gham-khadi. Individuals, describing their ghamkhadi experiences, offer discriminating accounts of their 'individual selves,' bound by imperatives other than those of their religion, supposed ethnic practice or Pukhtunwali, or class or family interest. In re-specifying a diverse body of practices of Pukhto (divided by gender, generation and location), this work sought to capture the dynamism of contemporary Pukhtunwali. With the move of Khan families to the city over the last thirty years, Pukhto is seen as having undergone a modification by almost all local people. One elder Pukhtun in his seventies, for example, thought the entire way of life had been lost. Others said it had simply 'changed'. For many, especially mullahs, practices among the elite have become westernized, to the detriment of Khan morality. I have argued that while the relative prominence of male notions of Pukhtunwali (as described in conventional anthropological accounts), such as male honour (gherat), trust (jabba), revenge (badal), male honour (nang), assembly of male elders (jirga), and manliness (saritob), have declined among the transregional Pukhtuns I worked with, others like ghamkhadi, hospitality (melmastia), and agnatic rivalry (tarburwali, indrorwali), have intensified. In presenting gham-khadi as engaging a wide network of people, this account has sought to mediate between male (Barth 1986) and female (Grima 1998) emphases in stressing the transitive and transactional elements of participation. Men and women kin and affines, close and distant relatives, rich and poor, and paid and unpaid attenders contribute to the festivities in different ways. On the theoretical level, Pukhtunwali may be grasped, in Laidlaw's terms, as a 'set of representations' (1995). Rather than having the character of a 'code', whose operations are invariant and which may only be changed wholesale, it forms a repertoire of actions integrally attached to social meanings and processes, but articulated in such a way that individual practices may emerge or fall into abeyance without the whole pattern undergoing resignification. Such a theoretical frame is useful in helping us to perceive the many innovations that are beginning to be introduced into gham-khadi by Al-Huda graduates.

'More than economics, more than philosophy, the crucial variable when considering any aspect of Pakistan is its religion, Islam' 
(Ahmed, A. S. 1977b: 4). Any ethnography of Pukhtun peoples must distinguish between proponents of different styles of being Muslim in advancing any characterization of social practices. While the Pukhtun Taliban are male, of poor background, and are educated through rote-learning in the madrasa by mullahs, Al-Huda graduates, particularly Pukhtun, are female, of relatively wealthy background and are preponderantly English-speaking and convent-educated. ${ }^{42}$ Representing an alternative mode of Islamic modernity to any simplistically-identified form of 'fundamentalism', Al-Huda seeks to make Pukhtun funerary procedures consonant with a scriptural reading of the Quran. In the face of critics who argue that Muslim girls leave convent-schools Christianized/westernized, Al-Huda graduates have taken issue with the prolongation of mourning beyond three days, in one case bringing the forty-day anniversary forward to coincide with the weekly Friday anniversary. More frequently, however, graduates introduce modifications into their styles of attendance, risking their social reputation by the appearance of rudeness when they leave after the third day (compare Shakry in Egypt 1998: 154). It should be noted, however, that these Bibiane are often as, or more, committed to the maintenance of Pukhtunwali as their contemporaries. In another apparent contradiction with their Islamic faith, Al-Huda graduates often continue to send their children to schools like the Catholic Murree Convent of Jesus and Mary, which they regard as an institution that has conventionally taken generations of Pukhtun girls, and a place of knowledge valuable under Islamic auspices. Indeed, the religious commitment of such Bibiane has been able to transcend the hostility that typically exists between the Khan and mullah classes (see Barth 1995:63; Caroe 1992: 426; many Khanan are said to perceive mullahs as 'narrow-minded', authoritarian and hypocritically fixated on what they proscribed [houri, alcohol, debauchery and homosexuality] while for the mullahs, the landed classes are perceived as 'infidels': Ahmed 1988: 191-192; Barth 1995). The two social factions are pitted against one another in the electoral process, a system largely riddled with corruption where votes are 'bought' in the context of reciprocal but asymmetrical agreements, such as in gham-khadi. Ironically, for the first time in the 2002 Pakistan elections, after the American rout of Afghanistan's Taliban government, Swat and Mardan returned a full slate of religious candidates, leading many politicians from influential

${ }^{42}$ Brenner locates a comparable Islamic women's movement in Java (1996: 68o); compare also Abu-Lughod 1998: 4, 15 . 
families to doubt the veracity of pledges received in their hujre and dere (men's houses). ${ }^{43}$

This sense of the slippage between public personae and private selves, as voters turned out to have concealed their intentions, also pervasively characterizes gham-khadi. Ceremonies occur in the midst of constant scrutiny, judgment and gossip (badly-dressed Bibiane are referred to as 'daigane'). Khalak (people, public opinion) shapes Bibiane's every move. The necessity of presenting an irreproachable public front arouses great anxiety in many Bibiane. This anxiety produces feelings of inadequacy or exhaustion, and ructions between family members. Women repeatedly stated that gham-khadi left little time for, variously, childcare, friendships, relaxation, reading or courses of study. Many women professed the desire to escape the obligations of Pukhto entirely. Knowing I lived abroad, one respectable village woman asked me in the most earnest manner to find her a position as a maid outside the country: just take me out of this Pukhtun society' (bus ma de dae Pukhtano zee na oobasa) (see also Grima 1998: 163; and Lindholm, Charles 1982: 193). For many, including Bibiane and their husbands, only emigration to Lundun (London, used as the term for Britain generally) or Amreeka (America) offers an outlet. Pukhtun Bibiane living outside Pakistan likewise praised the arrangement as having released them from what they saw as nonnegotiable obligations: a Bibi whose husband works in Dubai said that her children's schooling could now proceed uninterrupted by ghamkhadi. Future research into Pukhtun communities and elite immigrant Pukhtuns outside Pakistan is needed to broaden the present work by specifying gham-khadi as an international phenomenon.

However, translocation to Islamabad and the global dispersion of educated Bibiane open a space for flexibility in the 'work of life' (Donnan and Werbner 1991: 12). The internet makes possible new forms of sociality, adapting earlier practices. Recently, for example, my husband, Arsallah and I received email invitations in Cambridge where we live for Pukhtun weddings in the North-West Frontier Province of Pakistan. Technology also offers gradations of participation in ghamkhadi for expatriate and other Pukhtuns not present at collective

${ }^{43}$ In one instance, Bibiane of a family believed that they had successfully secured the votes of dependents for their father who stood for a position in national elections in exchange for wedding invitations. When their father was trounced by a mullah at the 2002 elections, however, they brandished sticks to drive back the poor (gharib) village wedding guests from their gates. 
events. In one case, hearing a younger nephew had died, an illiterate maid working in a Khan household in England recorded a message of condolence onto a cassette player, and sent the message to be played by the deceased's wife in Swat. It would certainly be premature to say that many people accept such mediated forms of gham as adequate substitution for personal attendance. Nevertheless, some negotiation between different degrees of presence and social participation in ghamkhadi events will develop. Otherwise, the arduousness of the "work of life" risks alienating many Bibiane, predominantly middle-aged, to whom their own lives seem less attractive than the opportunities now opening up for their daughters and granddaughters. Possibly only through such an adjusted economy of 'modern' and "customary" practices and allegiances can gham-khadi avoid being judged as what a few professional Khanan (one a medical doctor) summarily dismissed as a 'waste of time'.

But such a dissociation from Pukhto as it is imagined and experienced by most Pukhtun people would, for the majority, be understood as the loss or estrangement of those speakers' fundamental identity. As one older Bibi, sitting on a kat (straw bed) alongside various other visiting Bibiane, village guests, and maids-all sipping tea under a persimmon tree in the cool mountainous Swati breeze-told me,

'The world is established through the work of life!'

'Dunia pa zeest-rozgar wadana da!'

\section{Bibliography}

Abu-Lughod, L. 1986. Veiled Sentiments: Honour and Poetry in Bedouin Society. Berkeley: University of California Press.

Ahmed, A. S. 1975. Mataloona: Pukhto Proverbs. Karachi: Oxford University Press.

- 1976. Millennium and Charisma Among Pathans: A Critical Essay in Social Anthropology. London: Routledge and Kegan Paul.

- 1977b. Pieces of Green: The Sociology of Change in Pakistan. Karachi: Royal Book Company.

- 1980. Pukhtun Economy and Society: Traditional Structure and Economic Development in a Tribal Society. London: Routledge and Kegan Paul.

— 1988. The Mullah of Waziristan: Leadership and Islam in a Pakistani District. In Shari'at and Ambiguity in South Asian Islam (ed.) K. P. Ewing, 180-202. Berkeley: University of California Press.

Ahmed, A. 2004. 'The World is Established Through the Work of Existence'. The Performance of Gham-Khadi among Pukhtun Bibiane in Northern Pakistan. Ph.D. Thesis. University of Cambridge.

Alavi, H. 1991. Pakistani Women in a Changing Society. In Economy and Culture in Pakistan: Migrants and Cities in a Muslim Society (eds.) H. Donnan and P. Werbner, 124-142. London: Macmillan. 
Ali, A. Y. (trans.) 1989. The Holy Qur'an: Text, Translation and Commentary. Brentwood, Maryland, USA: Amana Corporation.

Ali, S. 2003. Pakistan Women Socialites Embrace Islam. BBC News (Thursday, 6 November).

Altorki, S. 1986. Women in Saudi Arabia: Ideology and Behaviour Among the Elite. New York: Columbia University Press.

Asad, T. 1972. Market Model, Class Structure and Consent: A Reconsideration of Swat Political Organisation. Man 7: 1, 74-94.

Baal, J. V. 1975. Reciprocity and the Position of Women. Assen/Amsterdam: Van Gorcum. Barth, F. 1986 (first published 1959). Political Leadership Among Swat Pathans. London: Athlone Press.

— 1995 (first edition 1985). The Last Wali of Swat: An Autobiography as told to Fredrik Barth. Oslo: Norwegian University Press.

Bellew, H. W. (n.d.). A Dictionary of the Pukkhto or Pukshto Language in which the Words are Traced to their Sources in the Indian and Persian Languages. Peshawar: Saeed Book Bank. Bourdieu, P. 1966. The Sentiment of Honour in Kabyle Society. In Honour and Shame: The Values of Mediterranean Society (ed.) J. G. Peristiany, 191-241. Chicago: The University of Chicago Press.

— 1991 (first published 1977). Outline of a Theory of Practice. Cambridge: University Press.

Bukhari, S. 1994. Summarized Sahih Al-Bukhari. Arabic-English (trans.) Dr. Muhammad Muhsin Khan. Riyadh, Saudi Arabia: Maktaba Dar-us-Sallam.

Caroe, O. 1992 (first published 1958). The Pathans: $55^{\circ}$ B.C. - A.D. I957. London: Macmillan and Company Limited.

Carsten, J. 1997. The Heat of the Hearth: The Process of Kinship in a Malay Fishing Community. Oxford: Oxford University Press.

Chhachhi, A. 1994. Identity Politics, Secularism and Women: a South Asian Perspective. In Forging Identities: Gender, Communities and the State in India (ed.) Z. Hasan, 74-95. Boulder: Westview Press.

Colen, S. \& Sanjek, R. 1990. Introduction: At Work in Homes 1: Orientations. In At Work in Homes: Household Workers in World Perspective (eds.) R. Sanjek and S. Colen, 1-13. Washington D.C.: American Ethnological Society Monograph Series, Number 3 .

Comaroff, J. \& Comaroff, J. 1992. Ethnography and the Historical Imagination. Boulder, Colorado: Westview Press.

Cook, M. 200o. Commanding Right and Forbidding Wrong in Islamic Thought. Cambridge: University Press.

Daniel, V. E. 1984. Fluid Signs: Being a Person the Tamil Way. Berkeley: University of California Press.

Donnan, H. \& Werbner, P. 1991. Introduction. In Economy and Culture in Pakistan: Migrants and Cities in a Muslim Society (eds.) H. Donnan and P. Werbner, 1-34. London: Macmillan.

Dupree, L. 1977. On Two Views of the Swat Pushtun. Current Anthropology 18: 3, $5^{1} 4^{-18}$.

Edwards, D. B. 1996. Heroes of the Age: Moral Fault Lines on the Afghan Frontier. Berkeley: University of California Press.

- 1998. Learning from the Swat Pathans: Political Leadership in Afghanistan, 1978-97. American Ethnologist 25: 4, 712-28.

Ewing, K. P. (ed.) 1988. Shari'at and Ambiguity in South Asian Islam. Berkeley: University of California Press.

Gilmartin, D. \& Lawrence, B. B. (eds.) 200o. Beyond Turk and Hindu: Rethinking Religious Identities in Islamicate South Asia. Gainesville: University Press of Florida. 
Gilsenan, M. 1990. Recognizing Islam: Religion and Society in the Modern Middle East. London: I. B. Tauris.

Goodwin, B. 1969. Life Among The Pathans. London: RAI- Museum of Mankind Library. Gray, J. N. \& Mearns, D. J. (eds.) 1989. Society from the Inside Out: Anthropological Perspectives on the South Asian Household. New Delhi: Sage Publications.

Grima, B. 1998. The Performance of Emotion Among Paxtun Women: 'The Misfortunes Which Have Befallen Me'. Karachi: Oxford University Press.

Grint, K. 1991. The Sociology of Work. Cambridge: Polity Press.

Hochschild, A. R. 1997. The Time Bind: When Home Becomes Work and Work Becomes Home. New York: Metropolitan Books.

Horvatich, P. 1994. Ways of Knowing Islam. American Ethnologist 21: 4, 81 1-26.

Howell, E. 1979. Mizh: A Monograph on Government Relations with the Mahsud Tribe. Karachi: Oxford University Press.

Humphrey, C. 1992. Women and Ideology in Hierarchical Societies in East Asia. In Persons and Power of Women in Diverse Cultures (ed.) S. Ardener, 173-92. New York: Berg.

Humphrey, C. \& Laidlaw, J. 1994. The Archetypal Actions of Ritual: A Theory of Ritual Illustrated by the Jain Rite of Worship. Oxford: Clarendon Press.

Jahoda, M. 1982. Employment and Unemployment: A Socio-Psychological Analysis. Cambridge: University Press.

Jansson, E. 1988. India, Pakistan or Pukhtunistan. Uppsala: Acta Universitatis Upsaliensis.

Kelly, M. P. F. 1986. Women's Work: Development and the Division of Labor by Gender. Massachusetts: Bergin and Garvey.

Khan, A. M. 1994. Da Pukhtunkhwa Ghag (In Pukhto). Sadar Pukhtunkhwa Quomi Party. Lahore: Millat.

Khan, Ali. 2003. Representing Children: Power, Policy and the Discourse on Child Labour in the Football Manufacturing Industry of Sialkot, unpublished Ph.D. dissertation, University of Cambridge.

Khan, G. 1990 (first published 1947). The Pathans. Islamabad: Pushto Adabi Society.

Khan, S. M. 1997. Pukhtuno Ka Tarekhe Safar (In Urdu). Karachi: Zaki sons.

Khoury, P. S. \& Kostiner, J. (ed.) 1990. Tribes and State Formation in the Middle East. Berkeley: University of California Press.

King, L. W. 1984. The Orakzai, Country and Clan. Lahore: Vanguard Books.

Kolenda, P. 1989. The Joint Family Household in Rural Rajasthan: Ecological, Cultural and Demographic Conditions for its Occurrence. In Society From the Inside Out: Anthropological Perspectives on the South Asian Household (eds.) J. N. Gray and D. J. Mearns, 55-106. New Delhi: Sage.

Kondos, V. 1989. Subjection and the Domicile: Some Problematic Issues Relating to High Caste Nepalese Women. In Society From the Inside Out: Anthropological Perspectives on the South Asian Household. (eds.) J. N. Gray and D. J. Mearns, 162-91. New Delhi: Sage.

Kurin, R. 1984. Morality, Personhood, and the Exemplary Life: Popular Conceptions of Muslims in Paradise. (196-220). In Moral Conduct and Authority: The Place of Adab in South Asian Islam (ed.) B. D. Metcalf, 196-220. Berkeley: University of California Press.

Laidlaw, J. 1995. Riches and Renunciation: Religion, Economy, and Society among the Jains. Oxford: University Press.

Le Wita, B. 1994. French Bourgeois Culture. Translated from the French by J.A. Underwood. Cambridge: University Press.

Lewenhak, S. 1980. Women and Work. London: Macmillan. 1992. The Revaluation of Women's Work. London: Earthscan Publications.

Lindholm, Charles. 1981. History and the Heroic Pakhtun. Man 16: 3, 46-467. 
1982. Generosity and Jealousy: The Swat Pukhtun of Northern Pakistan. Columbia University Press.

1988. The Social Structure of Emotional Constraint: The Court of Louise XIV and the Pukhtun of Northern Pakistan. Ethos 16: 3, 227-46.

- 1995. Quandaries of Command in Egalitarian Societies: Examples from Swat and Morocco. In Comparing Muslim Societies: knowledge and State in a World Civilization (ed.) J. R. I. Cole, 63-87. University of Michigan Press.

- 1996. Frontier Perspectives: Essays in Comparative Anthropology. Karachi: Oxford University Press.

Mackintosh, M. M. 1979. Domestic Labour and the Household. In Fit Work for Women (ed.) S. Burman, 173-91. London: Croom Helm.

Mandelbaum, D. G. 1993. Women's Seclusion and Men's Honor: Sex Roles in North India, Bangladesh and Pakistan. Tucson and London: The University of Arizona Press.

Marsden, M. 2002. Islamization and Globalization in Chitral, Northern Pakistan, unpublished Ph.D. dissertation. University of Cambridge.

Mauss, M. 1990. The Gift: The Form and Reason for Exchange in Archaic Societies. London: Routledge.

Merk, W. R. H. 1984. The Mohmands. Lahore: Vanguard Books.

Mernissi, F. 1985. Beyond the Veil: Male-Female Dynamics in Modern Muslim Society. London: Al Saqi Books.

Metcalf, B. D. (ed.) 1984a. Introduction. In Moral Conduct and Authority: The Place of Adab in South Asian Islam (ed.) B. D. Metcalf, 1-20. Berkeley: University of California Press.

- 1984b. Islamic Reform and Islamic Women: Maulana Thanawi's Jewelry of Paradise. In Moral Conduct and Authority: The Place of Adab in South Asian Islam (ed.)

B. D. Metcalf, 184-95. Berkeley: University of California Press.

- 1990. Perfecting Women. Berkeley: University of California.

Metcalf, P. 1982. A Borneo Journey into Death. Berawan Eschatology from Its Rituals. University of Pennsylvania Press.

Mohmand, J. S. 1966. Social Organization of Musa Khel Mohmand, unpublished M.A. Thesis, Punjab University, Pakistan.

Moore, H. L. 1997 (first published 1988). Feminism and Anthropology. Oxford: Polity Press in association with Blackwell.

Naveed-i-Rahat. 1990. Male Outmigration and Matri-Weighted Households: A Case Study of a Punjabi Village in Pakistan. New Delhi: Hindustan Publishing Corporation.

Nelson, C. 1974. Public and Private Politics: Women in the Middle Eastern World. American Ethnologist 1: 3, 551-63.

Nola, R. 1998. Foucault. London: Frank Cass.

Novarra, V. 1980. Women's Work, Men's Work: The Ambivalence of Equality. London: Marion Boyers.

Oppong, C. 1994. Introduction. In Gender, Work and Population in Sub-Saharan Africa (eds.) A. Adepoju and C. Oppong, 1-16. London: James Gurrey.

Pahl, R. E. (ed.) 1989. On Work: Historical, Comparative and Theoretical Approaches. Oxford: Basil Blackwell.

Paine, R. 1982. The Stamp of Swat: A Brief Ethnography of Some of the Writings of Fredrik Barth. Man 17: 2, 328-39.

Papanek, H. 1982. Purdah: Separate Worlds and Symbolic Shelter. In Separate Worlds: Studies of Purdah in South Asia (eds.) H. Papanek. and G. Minault, 5-53. Delhi: Chanakya Publications.

Pitt-Rivers, J. 1966. Honour and Social Status. In Honour and Shame: The Values of Mediterranean Society (ed.) J. G. Peristiany, 19-77. The University of Chicago Press.

Povinelli, E. A. 1993. Labor's Lot. Chicago: University of Chicago Press. 
Price, G. P. 200o. Acting in Public versus Forming a Public: Conflict Processing and Political Mobilization in Nineteenth Century South India. In Religion and Public Culture: Encounters and Identities in Modern South India (eds.) K. E. Yandell \& J. J. Paul, 27-55. Surrey: Curzon.

Rabinow, P. (ed.) 1986. The Foucault Reader. Harmondsworth: Penguin.

Raj, D. S. 1997. Shifting Culture in the Global Terrain: Cultural Identity Constructions Amongst British Punjabi Hindus, unpublished Ph.D. dissertation, University of Cambridge.

Raverty, H. G. 1982. A Dictionary of Puktho, Pushto or Languages of the Afghans. Peshawar: Saeed Book Bank.

Reagan, B. B. \& Blaxall, M. 1976. Introduction: Occupational Segregation in International Women's Year. In Women and the Workplace: The Implications of Occupational Segregation (eds.) M. Blaxall and B. Reagan, 1-5. Chicago: University of Chicago.

Reiter, R. R. 1975. Men and Women in the South of France: Public and Private Domain. In Towards an Anthropology of Women (ed.) R. R. Reiter, 252-282. New York: Monthly Review Press.

Reynell, J. 1985. Honour, Nurture and Festivity: Aspects of Female Religiosity amongst Jain Women in Jaipur, unpublished Ph.D. dissertation, University of Cambridge.

Richards, D. S. 1990. The Savage Frontier: A History of the Anglo-Afghan Wars. London: Macmillan.

Roded, R. (ed.) 1999. Women in Islam and the Middle East. London: I. B. Tauris.

Safdar, S. 1997. Kinship and Marriage in Pukhtoon Society. Lahore: Pak Book Empire.

Sexton, L. D. 1984. Pigs, Pearlshells, and 'Women's Work': Collective Responses to Change in Highland Papua New Guinea. In Rethinking Women's Roles (eds.) D. O'Brien and S. W. Tiffany, 120-52. Berkeley: University of California Press.

Shah, S. I. 1993. Socio-Economic Development in the Tribal Areas: A Case Study of Mohmand Agency (1975-85). Islamabad: National Institute of Pakistan Studies, Quaid-i-Azam University.

Shah, S. W. A. 1999. Ethnicity, Islam and Nationalism: Muslim Politics in the North West Frontier Province 1937-47. Karachi: Oxford University Press.

Shakry, O. 1998. Schooled Mothers and Structured Play: Child Rearing in Turn-of-the Century Egypt. In Remaking Women: Feminism and Modernity in the Middle East (ed.) L. Abu-Lughod, 126-7o. Princeton: University Press.

Shalinski, A. C. 1986. Reason, Desire, and Sexuality: The Meaning of Gender in Northern Afghanistan. Ethos 14: 4, 323-43.

Sharma, U. M. 1980. Purdah and Public Space. In Women in Contemporary India and South Asia (ed.) A. de Souza, 213-39. New Delhi: Manohar.

Shaw, A. 1997. Women, the Household and Family Ties: Pakistani Migrants in Britain. In Family and Gender in Pakistan: Domestic Organization in a Muslim Society (eds.) H. Donnan and F. Selier, 132-55. New Delhi: Hindustan Publishing Corporation.

- 2000. Kinship and Continuity: Pakistani Families in Britian. London: Routledge.

. 2001. Kinship, Cultural Preference and Immigration: Consanguineous Marriage Among British Pakistanis. Man 7: 2, 315 $5^{-34}$.

Sherani, S. R. 1991. Ulema and Pir in the Politics of Pakistan. In Economy and Culture in Pakistan: Migrants and Cities in a Muslim Society (eds.) H. Donnan and P. Werbner, 216-46. London: Macmillan.

Shinwari, S. A. 200o. One Hundred Years of Pashto Language and Literature. The Frontier Post. Peshawar: 13, Feb.

Shore, C. 2002. Introduction: Towards an Anthropology of Elites. In Elite Cultures: Anthropological Perspectives (ed.) C. Shore, 1-21. London: Routledge. 
Singer, A. 1982. Guardians of the North-West Frontier: The Pathans. Amsterdam: Time Life Books.

Singh, K. 1992. Women Entrepreneurs. New Delhi: Ashish Publishing House.

Smith, M. 1994. Rabi'a: The Life and Work of Rabi' $a$ and Other Women Mystics in Islam. Oxford: One World Publications.

Spain, J. W. 1962. People of the Khyber. New York: Frederick A. Praeger.

—. 1963. The Pathan Borderland. The Hague: Mouton.

- 1995. Pathans of the Latter Day. Karachi: Oxford University Press.

Strathern, M. 1984. Domesticity and the Denigration of Women. In Rethinking Women's Roles (eds.) D. O’Brien and S. W. Tiffany, 13-31. Berkeley: University of California Press.

- 1990 (originally published in 1988). The Gender of the Gift: Problems with Women and Problems with Society in Melanesia. Berkeley: University of California Press.

Tahir, M. N. 1980. Tappa ao Zwand (in Puktho). Peshawar University: Pukhto Academy.

Tair, M. N. \& Edwards, T. G. 1982. Rohi Mataluna (Pashto Proverbs). A collection of Pashto proverbs with translations into English. Peshawar: Pashto Academy, University of Peshawar.

Tapper, N. 1978. The Women's Subsociety Among the Shahsevan Nomads of Iran. In Women in the Muslim World (eds.) L. Beck and N. Keddie, 374-98. Cambridge, Massachusetts: Harvard University Press.

- 1991. Bartered Brides: Politics, Gender and Marriage in an Afghan Tribal Society. Cambridge: University Press.

Tapper, R. 1984. Holier Than Thou: Islam in Three Tribal Societies. In Islam in Tribal Societies: From the Atlas to the Indus (eds.) A. S. Ahmed and D. M. Hart, 244-265. London: Routledge and Kegan Paul.

- 2001. Anthropology and (the) Crisis (pp. 13-16). Anthropology Today 17: 6, $13-16$.

Thackston, W. M. 1999. The Jahangirnama: Memoirs of Jahangir, Emperor of India. Oxford University Press: Washington D.C.: Smithsonian Institute.

Tiffany, S. W. 1984. Introduction: Feminist Perceptions in Anthropology. In Rethinking Women's Roles (eds.) D. O'Brien and S. W. Tiffany, 1-11. Berkeley: University of California Press.

Titus, P. 1998. Honor the Baloch, Buy the Pushtun: Stereotypes, Social Organization and History in Western Pakistan. Modern Asian Studies 32, 657-87.

Torab, A. 1996. Piety as Gendered Agency: A Study of Jalaseh Ritual Discourse in an Urban Neighbourhood in Iran. Journal of the Royal Anthropological Institute 2: 2, $235^{-52}$.

Turner, C. 2000. The Muslim World. Gloucestershire: Sutton Publishing Limited.

Wadud, M. A. 1962. The Story of Swat. (trans.) Ashruf Altaf Husain (told to Muhammad Asif Khan). Peshawar: Ferozsons.

Wallace, C. 1987. For Richer, For Poorer: Growing up in and out of Work. London: Tavistock Publications.

Wallman, S. 1979. Introduction: A Social Anthropology of Work? In Social Anthropology of Work (ed.) S. Wallman, 1-24. London: Academic Press.

Ward, H. 1997. Worth its Weight: Gold, Women and Value in North West India, unpublished Ph.D. dissertation, University of Cambridge.

Waterson, R. 1990. The Living House: An Anthropology of Architecture in South-East Asia. Oxford: University Press.

Weber, M. 1968. The Protestant Ethic and the Spirit of Capitalism. (trans.) Talcott Parsons. London: Allen and Unwin.

Weiss, A. M. 1991. Introduction: Industrial Development and Social Change. In Culture, Class, and Development in Pakistan: The Emergence of an Industrial Bourgeoisie in Punjab, Weiss, 1-18. Boulder: Westview Press. 
1998. The Slow yet Steady Path to Women's Empowerment in Pakistan. In Islam, Gender and Social Change (eds.) Y. Y. Haddad and J. L. Esposito, 124-43. New York: Oxford University Press.

Werbner, P. 1986. The Virgin and the Clown Ritual Elaboration in Pakistani Migrants' Weddings. Man 21: 2, 227-50.

- 1992. Processes of Community Formation (in Commentaries). American Anthropologist 94: 4, 926.

York, S. 1997. Beyond the Household: An Exploration of Private and Public Spheres in the Yasin Valley. In Family and Gender in Pakistan: Domestic Organization in a Muslim Society (eds.) H. Donnan and F. Selier, 208-33. New Delhi: Hindustan Publishing Corporation.

Yusuf, A. A. (trans.) 1989. The Holy Qur'an. Brentwood, Maryland, USA: Amana Corporation. 